\title{
EMPLOYERS, INDUSTRIAL HOUSING AND THE EVOLUTION OF COMPANY WELFARE POLICIES IN BRITAIN'S HEAVY INDUSTRY: WEST SCOTLAND, 1870-1920*
}

The history of working-class housing has become an important area of urban studies in recent years, as detailed investigations of building activities and property relations uncover the origins of housing initiatives. ${ }^{1}$ The growth of cities in the industrial North of England created their own peculiar building styles and housing problems, whilst the great metropolis of London continued to attract thousands of families into its eternal slums. ${ }^{2}$ There were also the new boom towns of manufacturing Britain, specialising in particular products as a regional division of productive expertise emerged. Swindon and Crewe flourished in the railway age of the nineteenth century, whilst Barrow and Jarrow belonged to a later period of iron and steel shipbuilding. ${ }^{3}$ The latter settlements were dominated not only by a few vital products, but by a handful of large companies with massive resources, which enabled them to undertake the housing of their first workers. ${ }^{4}$ These accounts may be complemented by the evidence of working-class dwellings in the early textile villages and larger industrial colonies of Lancashire and West Riding, or by the scattered documentation on the colliery villages which persisted through the major coal fields well into the twentieth century. ${ }^{5}$

* My appreciation and thanks for the encouraging advice and criticism of Keith Burgess, Sydney Checkland, Roy Hay, Alan Macgregor and the editors of this journal.

1 The History of Working Class Housing, ed. by S. D. Chapman (Newton Abbot, 1971); E. Gauldie, Cruel Habitations: A History of Working-Class Housing, 1780-1918 (London, 1974).

2 A. S. Wohl, The Eternal Slum: Housing and Social Policy in Victorian London (London, 1977), pp. 21-44.

3 J. D. Marshall, Furness and the Industrial Revolution (Barrow-in-Furness, 1958), pp. 249-80, for earlier railway development and the later iron-making progress.

4 W. H. Chaloner, The Social and Economic Development of Crewe (Manchester, 1950), pp. 40-66 and passim, for one important example.

5 J. D. Marshall, "Colonisation as a Factor in the Planting of Towns in North-West England", in: The Study of Urban History, ed. by H. J. Dyos (London, 1968), pp. 215-17, 221 , for example. 
Despite the undoubted prominence of industrial enterprises in constructing working-class accommodation at different stages of urban growth, existing literature conveys a confused impression of business intervention in the housing market. There are considerable differences in interpretation and emphasis, as well as in the subjects surveyed, which makes generalisation on the evolution of employers' housing extremely difficult. Most writers dealing with the subject of industrial dwellings have not been primarily interested in housing, but the wider themes of business development or labour conditions. Those apologists for Victorian entrepreneurship have frequently attempted to demonstrate the genuine concern of industrialists for the living standards of their employees, and given the concentration of historians' attention on the large, progressive and successful firms of pre-war Britain this has not been an impossible task. ${ }^{6}$ Such studies tend to reinforce the self-promoting efforts of such "model" employers as Cadbury, Lever, Rowntree and others, who engaged in the creation of planned garden suburbs around their works and whose achievements continue to capture the imagination of many urban historians. ${ }^{7}$ The influence of such exceptional experiments may have been considerable in their implications for later generations of town planners, but they provide few clues as to the scale or character of company housing in the rest of Britain before $1914 .{ }^{8}$ Work completed on the earlier periods of housebuilding suggests that the responses of employers were almost always pragmatic and piecemeal, whilst their regard for standards and design was usually less than enlightened. ${ }^{9}$

Other writers on industrial housing have been strongly critical of both their general condition, and the uses made of such dwellings by ruthless managements. Studies of the coal-mining industry have revealed both the extent of housebuilding during the nineteenth century, and its deployment in periods of intense conflict between miners and masters. ${ }^{10}$ Very recent research by Daunton, however, offers a number of important correctives to traditional impressions of miners' housing, demonstrating the extent of

${ }^{6} \mathrm{Ch}$. Wilson, The History of Unilever: A Study in Economic Growth and Social Change (London, 1954); for example: A. Briggs, Social Thought and Social Action: A Study of the Work of Seebohm Rowntree (London, 1961).

7 M. Swenarton, Homes Fit for Heroes: The Politics and Architecture of Early State Housing in Britain (London, 1981), ch. 1, for example.

${ }^{8}$ C. W. Chalklin, "Housing Estates in the 18th Century", in: Urban Studies, VIII (1965), pp. 71-72; J. N. Tarn, "Housing in Liverpool and Glasgow: The growth of civic responsibility", in: Town Planning Review, XXXIX (1968-69), pp. 319-34.

9 S. Pollard, "The Factory Village in the Industrial Revolution", in: English Historical Review, LXXIX (1964), pp. 518, 529, passim; J. Lowe, "Industrial Houses and Settlement Patterns at Nantyglo, 1811-45", in: Monmouth Antiquarian, III (1977), p. 196.

10 R. Challinor, The Lancashire and Cheshire Miners (Newcastle, 1972), for example. 
fresh building after the 1870's in coal fields as distinct as Durham and South Wales. ${ }^{11}$ His study illustrates the considerable diversity within (as well as between) major coal regions, and the complexity of tenure agreements between masters and men. ${ }^{12}$ Coal owners' dwellings became enmeshed in the system of collective bargaining and customary relations of the industry, with the issue figuring in the workplace and district negotiations of the Durham area after $1880 .{ }^{13}$ The increasing burden of rent-free housing upon firms facing difficult market conditions and the violent oscillations of trade cycles, which left miners sitting unemployed in owners' property without rental obligations, provoked attempts to break the tied house arrangements by Durban masters.

Yet Daunton fails to encompass the broader questions of labour management and regulation which these controversies over industrial housing raised, presenting the owners' actions largely in the light of a rational response to the burdens of fixed capital costs. ${ }^{14}$ The subject of class conflict on the housing question is dealt with under the heading of "social control", which Daunton argues is a weak explanation of employers' building commitments. ${ }^{15}$ From the author's own evidence, we may question if this is entirely adequate, since the growing power and unionisation of the miners was itself one of the constraints which colliery firms faced in their attempts to reduce operating costs. Previously the most important and elastic element in production, labour was now organising in such a way that the reliance on housing to create an adequate and tractable workforce was no longer effective. Resistance of the workforce forced colliery managements to consider other means of reducing labour - as well as capital - costs, of which rent-free accommodation was one potential saving. This does not prove that labour regulation was a marginal consideration, but that the effectiveness of housing allocation as a method of enforcing discipline had been substantially weakened by unionisation.

Daunton's research raises a number of significant conceptual, as well as empirical, questions concerning the extent and function of owners' housing after 1870. It is arguable that the distinction which his essay makes, between rational market choices on one side and "social control" considerations on the other, is of limited value. Workplace conflict and labour resistance in different areas of production itself changed the nature of the

11 M. J. Daunton, “Miners' Housing: South Wales and the Great Northern Coalfield, 1880-1914", in: International Review of Social History, XXV (1980), p. 148.

12 Ibid., pp. 149, 157.

13 Ibid., pp. 164-65; Pollard, "The Factory Village in the Industrial Revolution", loc. cit., p. 517 , also.

14 Daunton, “Miners' Housing”, pp. 164-66.

15 Ibid., pp. 157-58. 
market calculation for employers. In practice they could not, as they well recognised, treat workers as merely another element of production which could be manipulated according to market demand. Social relations and labour subordination were essential aspects of industrial capitalism, and the provision of housing only extended these fundamental relations into the area of consumption, whilst placing it on the collective-bargaining agenda. Housing was clearly provided to meet the labour requirements of industrialists, though the definition of these needs did not necessarily follow any objective or logical measurement of shortages. Thus housing might be provided to emphasise the gradations of an industrial hierarchy, or to weaken the market position of existing employees, rather than from an absolute shortage of labour.

Market forces generated beyond the confines of the industry or firms involved were also significant considerations in the decisions of employers to undertake building activities. This involved the availability of capital loans, as well as the ability of local builders to deal with shortages independently of the industrialists' efforts. Local conditions could be considerably complicated by the cyclical fluctuations in the building trades, perhaps even providing overlapping skills to those in manufacturing industry, and therefore interacting with the labour flows and production opportunities experienced in a staple industry. ${ }^{16}$ Within the same manufacturing or extractive industry, there were significant variations between firms in similar geographical or economic positions in regards to housing choices. Particular employers developed labour-management strategies which provoked serious resistance or, alternatively, acted to secure a passive and contented workforce. The relative value of housing as an investment decision can only be fully appraised when these general policies are brought into view. For these reasons, it is vital that industrial housing should be evaluated in terms of general management policies within the enterprise, rather than simply as a contribution to working-class housing. The provision of accommodation was only one in a range of services introduced by industrialists during the nineteenth century. Some writers have suggested that such company welfare amenities were largely confined to larger or progressive concerns in the "new" consumer industries of the late nineteenth century, operating in reasonably protected domestic markets and sheltered from the harsh climate of competition facing the colliery owners. ${ }^{17}$ This may again be questioned as one example

16 J. H. Treble, "The Market for Unskilled Male Labour in Glasgow, 1891-1914", in: Essays in Scottish Labour History, ed. by I. MacDougall (Edinburgh, 1978), pp. 117-18 and passim for the Glasgow context.

17 P. Mathias, The First Industrial Nation (London, 1969), p. 375, for example. 
of the pervasive ideology of business enlightenment, which characterises industrial services as expressions of employer benevolence and advanced management thinking. Heavy industry developed its own forms of social provision beyond the wage contract, again with specific labour needs in view.

More generally, we may assess the significance of employers' housing in the context of wider class relations and the contact between industry and the State. From the 1870's, the government intervened in the housing market to an increasing extent, in a series of measure which enabled local authorities to engage in slum clearance and the construction of fresh dwellings. Existing Friendly Society legislation permitted the establishment of "utility societies", which operated under the Registrar and secured favourable terms for the raising of capital for building. Public loan facilities were also improved in a measure passed before the outbreak of war, which enabled private parties to raise public bonds for the purpose of increasing accommodation. ${ }^{18}$ There were more explicit connections between industrial production and government departments as a result of the shifting balance of expenditure within the British imperial State. During the 1890 's, there began a succession of substantial armaments and naval building programmes which exerted a powerful influence on the productive specialisation of many heavy industries. Engineering and shipbuilding enterprises discovered the massive returns to be made from military contracts, with a handful of large armaments firms able to capture the bulk of available orders and thereby develop steel, shipbuilding and engineering empires based on government demand. So vital became the attraction of scarce, skilled labour that State officials were prepared to sanction housing projects at government dockyards and arsenals, as well as encouraging similar plans at the works of private contractors. ${ }^{19}$ Dissatisfaction over housing amenities was no longer an uncomfortable fact of life for coal owners and similar employers: it became an issue of strategic importance where capitalists and officials were driving for an increase of production.

It is within this varied interplay of economic and political forces that we must locate and evaluate the growth of company housing in the decades after 1870 . Housing was one important aspect of an evolving welfare policy in many enterprises, which was primarily concerned with the creation and management of an efficient labour-force. The forces shaping industrial and class relations also provided scope for a series of alternative approaches to the housing problems of industrial workers. Their employers had at least four options, having once decided that the construction of

18 Swenarton, Homes Fit for Heroes, op. cit., pp. 32-33 and passim.

19 See the example of William Beardmores given below. 
dwellings was a desirable policy. Firstly, the firm might finance the erection (or the purchase and improvement) of houses themselves - which most properly deserves the description "company housing". Secondly, employers could offer private speculative builders the capital or land on favourable terms, with which the speculator could untertake operations. On completion he might sell the dwellings to the industrial concern or upon the open market, depending on the employer's arrangements. Thirdly, industrialists might initiate or sponsor and support, a public utility society or even building society and reap the advantages of local housing without intervention. Finally, business enterprises were sometimes able to reach an agreement with State agencies on the terms for undertaking housing. This could vary from a loan raised with the Public Works section of the Local Government Board, to direct security from government departments interested in the military orders completed by a particular enterprise. The course which an individual employer adopted depended on the circumstances in which he found himself. Each represented a commitment to housing in some form, though the outlay required on direct housing meant that many concerns preferred to operate via autonomous agencies or with State support as the decades passed.

With these themes in mind, it is possible to examine the housing provisions made by shipbuilding employers in the West of Scotland for fifty years after 1870. The industry was neither an acknowledged "new" consumer sector, nor was it amongst the traditional staples of the Industrial Revolution. Its industrial relations was characterised neither by the tranquility of certain female-dominated sectors, nor the coherent bitterness of colliery districts. The industry stood in a peculiar relationship to the State, given the scale of the naval race from the 1890's, but it also relied upon a massive amount of civil and mercantile building to sustain itself. In these respects, the industry offers an interesting case study for both housing activities and welfare provisions in these decades. The sample of firms reviewed below is not extensive, but it does offer a number of insights into the management policies of British industrialists in these critical years of economic change and social conflict.

\section{Constructing prosperity: shipbuilding and building in the regional context}

The remarkable success of British shipbuilding after 1870 can be largely explained in terms of favourable factor endowment, including the existence of a highly skilled and adaptable workforce, and the advantages of market conditions with British vessels constituting the greatest proportion of both mercantile and naval craft before $1914 .^{20}$ Its very scale gave 
considerable scope for specialisation within the industry, with specific yards able to meet the very particular requirements of individual customers in an age when every ship demanded its own design and planning. ${ }^{21}$ The relatively limited degree of mechanisation and deployment of capital equipment combined with the labour-intensive character of construction to give British yards a distinct advantage during the deep troughs of depression in an industry notorious for the violent oscillations of its building cycles. ${ }^{22}$ Employers relied on their tradesmen not merely to organise separate tasks and training within the yards, but to adapt new techniques and materials in the decades of change after 1870 . The rapidity with which shipbuilders devised and developed their separate handicrafts must be counted as a major factor in the continuing success of shipbuilding at this period.

The ascendancy gained by the West of Scotland within this expanding British industry has again to be explained in terms of labour qualities as well as natural resources. There had been shipyards in the region since the early eighteenth century, but the Clyde itself was a poorly dredged and unpromising location for the metropolis of British vessel building. ${ }^{23}$ It was the coming of steam propulsion and the use of iron fabrication that gave the area's iron and coal deposits a real significance, and by the 1860 's larger iron ships were already being launched on this Northern river - being itself improved by the work of the Clyde Trustees. ${ }^{24}$ Following the resurgence of activity from 1875, Clydeside continued to dominate the growth of building until in 1913 the river was producing more than 750,000 tons - or one third of all tonnage launched in the United Kingdom. ${ }^{25}$ Scottish yards were not only better placed for raw materials and assisted by the mechanical genius of native engineers during the nineteenth century, but were also larger than their English rivals, with five firms commanding between 2,300 and 3,600 men each by $1870 .^{26}$ The scale and sophistication of the works demanded the development of management hierarchies early in the in-

${ }^{20}$ S. Pollard, "British and World Shipbuilding, 1890-1914: A Study in Comparative Costs", in: Journal of Economic History, XVII (1957), p. 444 and passim.

21 Id., "The Economic History of British Shipbuilding"(Ph.D. thesis London. 1951), pp. 75-85; P. L. Robertson, "The Management of Manpower in British Shipbuilding, 1870-1914" (Ph.D. thesis Wisconsin, 1972), pp. 38-40, 47-49, etc.

22 Pollard, "British and World Shipbuilding", loc. cit,; W. S. Cormack, "An Economic History of Shipbuilding and Marine Engineering" (Ph.D. thesis Glasgow, 1930), p. 194.

23 Cormack, "An Economic History", pp. 2, 27-28, 40.

24 Ibid., p. 68; A. Slaven, The Development of the West of Scotland (London, 1975), p. 127.

${ }^{25}$ Slaven, The Development of the West of Scotland, pp. 178-79; Robertson, "The Management of Manpower", op. cit., p. 38.

26 Cormack, "An Economic History", p. 194. 


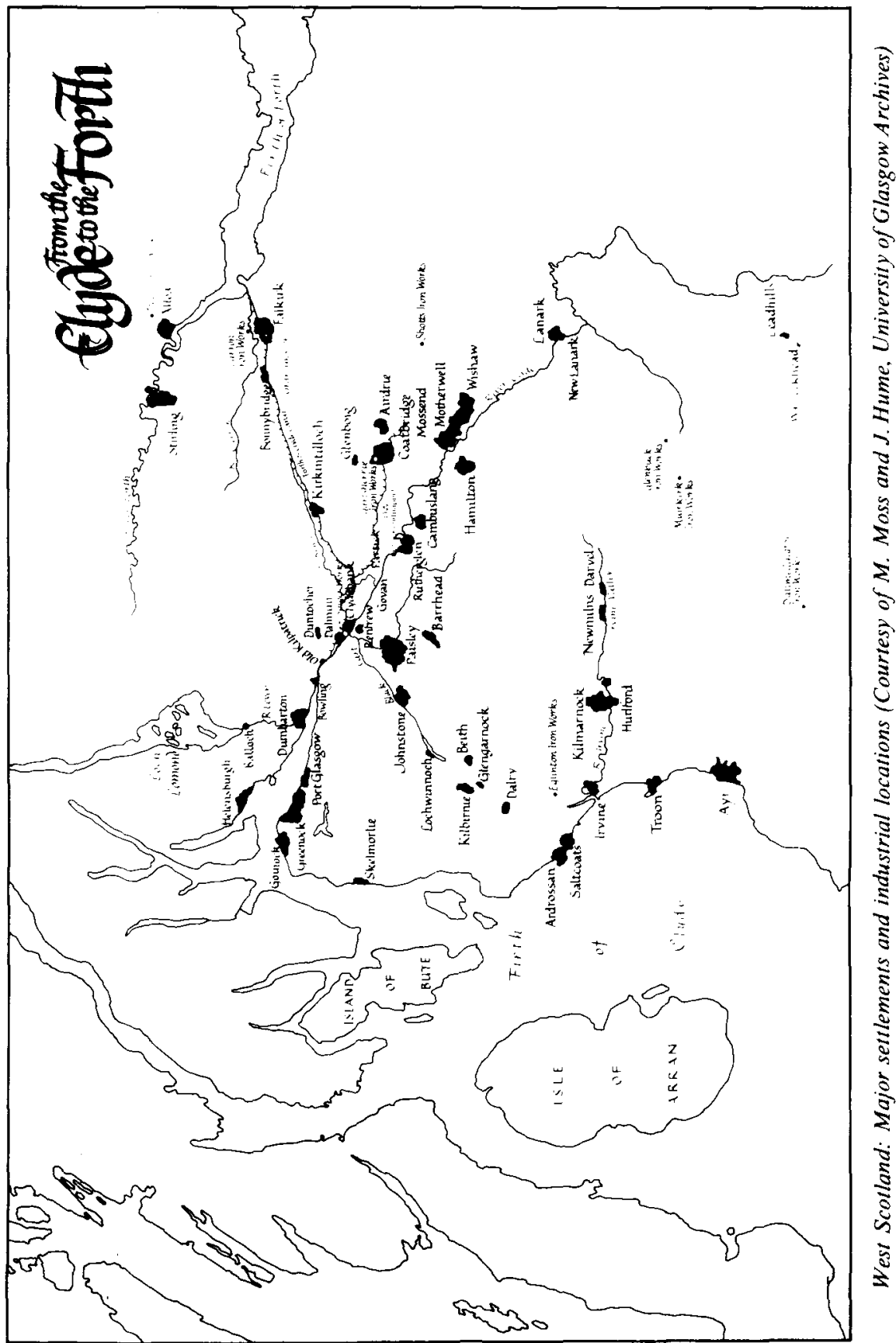


dustry's history, though inherent difficulties and physical obstacles prevented the extension of close supervision to the yards, and accounted for the survival of piecework and payment systems well into the next century. ${ }^{27}$

One of the most important factors in Clydeside's favour was the comparative weakness of traditional craft societies, particularly the Shipwrights, and the ease with which Scottish yards developed iron-working techniques using the cheaper labour organised by the Boilermakers' Society. ${ }^{28}$ In such an industry, a good supply of steady skilled workmen meant the difference between success and failure. Important innovations did occur in the use of machine tools and electrical power after 1890, but this equipment continued to be deployed manually by workmen moving around the vessels under construction. ${ }^{29}$ The typical shipbuilding enterprise continued to be dominated by family interests with a strong personal involvement in the concern; more systematic management did evolve after 1870 , and there were important advances in organisation of production and the hierarchical division of responsibilities or labour. ${ }^{30}$ Equally significant was the trend towards a growing integration of interests in coal, steel, shipbuilding and armaments from the 1890's. ${ }^{31}$ Iron and steel manufacturers entered the production of vessels and ordnance in pursuit of the considerable profits to be made from imperial rivalries and naval building during the pre-war period. Many of the largest yards were anxious to cultivate closer contact with government departments in search of lucrative contracts, and many personnel trained in the Admiralty or War Office were offered positions in private firms hoping to use the steady stream of orders to offset some of the difficulties experienced during the violent troughs of the years up to $1914 .^{32}$ Having invested such vast resources in the acquisition of shipyards and ordnance works which provided a direct outlet for armoured steel plate and engineering products,

27 Jotting Books of William Denny (1861-70), Denny Papers, University of Glasgow Deposit, 24 February and 9 March 1870, for piecework and foremen's role.

28 S. Pollard, "The Decline of Shipbuilding on the Thames", in: Economic History Review, Second Series, III (1950-51), pp. 74-76, 81 .

29 F. J. Rowan, "Recent Practice in the Application of Electricity to Engineering Tools", in: Transactions of the Institute Engineers \& Shipbuilders in Scotland, XL (1896-97), pp. 159-60; A. P. M. Fleming, “Apprenticeship Training”, ibid., LXI (1917-18), pp. 82, 123, for indication of some advances.

30 Slaven, The Development of the West of Scotland, p. 182, notes reduction in firms from 43 to 38 in 1870-1913.

31 Ibid.; see Jotting Books of William Denny for advanced practices.

32 J. D. Scott, Vickers: A History (London, 1962), pp. 46-60; E. Allen et al., The North-East Engineers' Strikes of 1871 (Newcastle, 1971), pp. 23-24, for the parallel case of Armstrongs in the North-East. 
industrialists devoted their energies to ensuring government expenditure continued to provide an effective demand when commercial prosperity was "threatened" by foreign powers and private orders were lacking.

The implications of these innovations for the organisation of both capital and labour were quickly recognised in areas like Clydeside. Attempts at tighter supervision of work and workplace discipline, coupled with technical change, organisational reforms and fresh payment systems, led to a series of bitter disputes around forms of control at work up to 1914. ${ }^{33}$ They culminated in the great struggles of the war itself, particularly those which occurred from autumn 1916 as employers sought to impose fresh dilution procedures and bonus schemes. Mechanisation was accelerated and interchangeability of tasks extended precisely at the time that scarcity of tradesmen gave them a powerful basis for resistance in the labour market. The strategic advantages of labour supply were never more obvious and the means to achieve it rarely more difficult.

The very pace and scale of industrial change after 1870 presented the West Scotland building industry with considerable problems in meeting the call for adequate housing. Established shipbuilding burghs such as Greenock, Govan and Partick found themselves almost overwhelmed by the immigration of workers to man the engineering and vessel construction works. The boom towns created by the sensational growth of the industry, such as Clydebank and Dalmuir, pressed ahead with large-scale building activity throughout the years to $1914 .{ }^{34}$ Housing initiatives were seen in both types of industrial locale during the great construction peaks of the 1870's and 1890's, as builders sought to satisfy the demand for workingclass tenements and cottages, as well as industrial and commercial premises. ${ }^{35}$ As in the South Wales coal region and Lancashire textiles, the general pace of regional growth gave a powerful impetus to such a localised industry as building. ${ }^{36}$

There were also serious deficiencies created by the private market system which presented Clydeside with a variety of housing problems in the decades after 1870. Many of these difficulties derived from the nature of property distribution and tenure relations in the Scottish context: the powerful hold of the landed interests over smaller burghs and urban

33 J. Melling, "Non-Commissioned Officers': British employers and their supervisory workers, 1880-1920", in: Social History, V (1980), for a discussion of disputes.

34 R. G. Rodger, "Speculative Builders and the Structure of the Scottish Building Industry, 1860-1914", in: Business History, XXI (1979), p. 240, table V.

35 Ibid., p. 228, table II.

36 S. B. Saul, "House Building in England, 1890-1914", in: Economic History Review, Second Series, XV (1962-63), pp. 121-22, and passim, for discussion of regional variations. 
centres was perpetuated by the ancient system of feu rents, burdening builders and tenants alike. ${ }^{37}$ The growing efficiency of local capital markets and alternative avenues of investment combined with the drawbacks of the property-bond practice to deter many investors after the 1870 's. ${ }^{38}$ Rising interest rates often dampened down the necessary optimism of the speculative builder, whilst the commissions exacted by the host of legal agents and factors who administered much of Scottish housing property reduced the margins returning to owners.

Underlying these trends were perhaps more fundamental disjunctures in the organisation of the industry and the impact of its cyclical fluctuations. On the supply side the crucial factor seems to have been the utilisation of labour, in a sector noted for the absence of capital equipment and the craft organisation of the workplace. As in shipbuilding, the trade societies continued to exercise a strong hold over working methods and production techniques long after the rise of the larger builder or general contractor ${ }^{39}$ The high proportion of skilled journeymen and the physical obstacles to mechanisation and close supervision resulted in a considerable degree of autonomy, including that of the stone masons, who played such an important role in Scottish housing. Such workers often faced the uncertainties of unemployment and the persistence of unfair practices, but were also able to move from artisan to master (or at least small subcontractor) with much greater ease than craftsmen in engineering or shipbuilding. The ability of the building societies to resist unwelcome innovations exasperated such ruthless managerialists as W. D. Weir, the Cathcart engineering master, who expressed his determination to break craft autonomy through the introduction of prefabricated dwellings and the use of new building materials. ${ }^{40}$

It was on the demand side that the most serious distortions were seen at this period, with a surge of demand coming usually after the building boom had passed its peak or with many groups simply unable to provide an effective level of demand for adequate accommodation. Labour migration within and beyond the region created fresh labour markets in areas where employment was available, and as larger shipbuilders moved to greater space and deeper water further downstream at Clydeside, there were

37 Rodger, "Speculative Builders", pp. 231-34, for landed interests.

38 Housing, Social Policy and the State, ed. by J. Melling (London, 1980), pp. 14-28, for some comments on the wider context.

39 Treble, "The Market for Unskilled Male Labour in Glasgow", loc. cit., p. 118; R. Price, Masters, Unions and Men: Work Control in Building and the Rise of Labour, 1830-1914 (Cambridge, 1980), pp. 164-97 and passim, for an exaggerated account of workplace change.

40 W. J. Reader, The Weir Group (London, 1971), p. 100 and passim. 
significant movements of workers. It was in these growth areas surrounding Glasgow that the presence of the larger speculative builder was most in evidence before $1914 .^{41}$ There remained, however, strong resistance to the payment of rising rents in these crowded burghs, and many tradesmen were simply unwilling to countenance the high levels demanded at towns like Clydebank. This inability and unwillingness to generate private housebuilding had been apparent for the most deprived groups during the 1850 's and 1860's in Glasgow itself, with local government forced to legislate for the improvement of basic lodgings and the demolition of decayed property. The Glasgow Improvement Trust arose in the vacuum created between slum dwellers, profiteering landlords and reluctant builders during these years.$^{42}$ By the turn of the century, there were signs that the threshold of effective demand had been reached for the affluent artisans, as better housing stood empty and working-class families suffered from overcrowding and poor amenities. ${ }^{43}$ Even skilled shipyard workers were unable to pay the kind of rent which made it reasonably profitable to build and buy dwellings as investments.

The problems of such groups were compounded by the growing unemployment amongst the building trades themselves, as carpenters and joiners were driven into the shipyards thereby depressing the general level of wages for tradesmen. ${ }^{44}$ Industrialists were not powerful enough in either propertied or political terms to remedy a situation from which they could still derive the benefit of cheap labour. Urban bourgeois employers such as the great publishing firms of Blackie and Collins had been responsible for many of the progressive initiatives during the mid century, including the Improvement Trust. ${ }^{45}$ Shipbuilders and engineers concentrated their interests and energies outside the city boundaries, and were unwilling to interfere with the complicated labyrinth of property relations until directly affected. After the 1870's they often found, however, that housebuilding was lagging badly behind industrial development in key areas of growth and were disturbed to find that speculative activity virtually ceased for a decade after 1878, and dried up altogether after $1903 .{ }^{46}$

41 Rodger, "Speculative Builders", pp. 229-31, for limited scope of speculative building.

42 C. M. Allan, "The Genesis of British Urban Redevelopment with special reference to Glasgow", in: Economic History Review, Second Series, XVIII (1965), pp. 598-601, 604. 43 J. Butt, "Working-Class Housing in Glasgow, 1900-39", in: Essays in Scottish Labour History, op. cit., pp. 146-47.

44 Treble, "The Market for Unskilled Male Labour in Glasgow", pp. 118-22, 13132; Rodger, "Speculative Builders", p. 240.

45 Allan, "The Genesis of British Urban Redevelopment", loc. cit., pp. 603-04, for the career of Blackie.

46 Rodger, "Speculative Builders", p. 234. Housebuilding declined from 2,660 to 102 per annum in 1903-14. 
In this deteriorating situation there occurred a series of organised protests against shortages and rent increases, ranging from a campaign in Dumbarton during the 1880 's to the great series of tenant movements before the First World War. This particular aspect of market resistance by working people was sharpest in the hard-pressed shipbuilding districts, which embraced engineering and boiler making as well as vessel launchings, with skilled workers (and their families) joining professionals and shopkeepers in opposition to rent rises, rate increases and letting arrangements at this time ${ }^{47}$ Like the in dustrial conflicts over workplace conditions and controls, housing unrest culminated in the great conflicts of the war itself, necessitating intervention by the central State.

\section{Shipbuilding employers and industrial housing, 1870-1920}

The housing activities of local industrialists must be situated in this context of economic growth and market deficiencies, as employers sought to establish labour reserves to supply sectors like shipbuilding. Although there were over twenty yards in the burghs around the old city of Glasgow, there were no major firms within the boundaries of this second imperial city. ${ }^{48}$ The physical expansion and movement of these operations demanded a steady recruitment of workers at the period of growth and increasing capital investment, with scarce resources rarely available for large housing projects. Yet the vital importance of trained employees and the complex changes after the 1870's indicated the urgency of securing accommodation where private investment could not be relied upon. It was with these wider perspectives in mind that shipbuilders calculated the costs and benefits of housing investment, and the needs of the workplace - with its management hierarchies - were never far from the discussions of immediate shortages.

Such calculations were made primarily within the individual enterprise and with local competition very much in view, though the capacity of employers to implement a housing policy depended on their various resources and the specific needs they articulated. This suggests that it is to the separate concerns that we must look for evidence of motivation in the construction of company dwellings, and in terms of business expenditure that we must assess the real significance of housing for industrial development. The following survey examines a group of prominent shipbuilding enterprises operating in the West of Scotland during these decades,

47 J. Melling, "Clydeside Housing and the Evolution of State Rent Controls, 1900-1939", in: Housing, Social Policy and the State, op. cit., for discussion.

48 Cormack, "An Economic History", p. 192. 


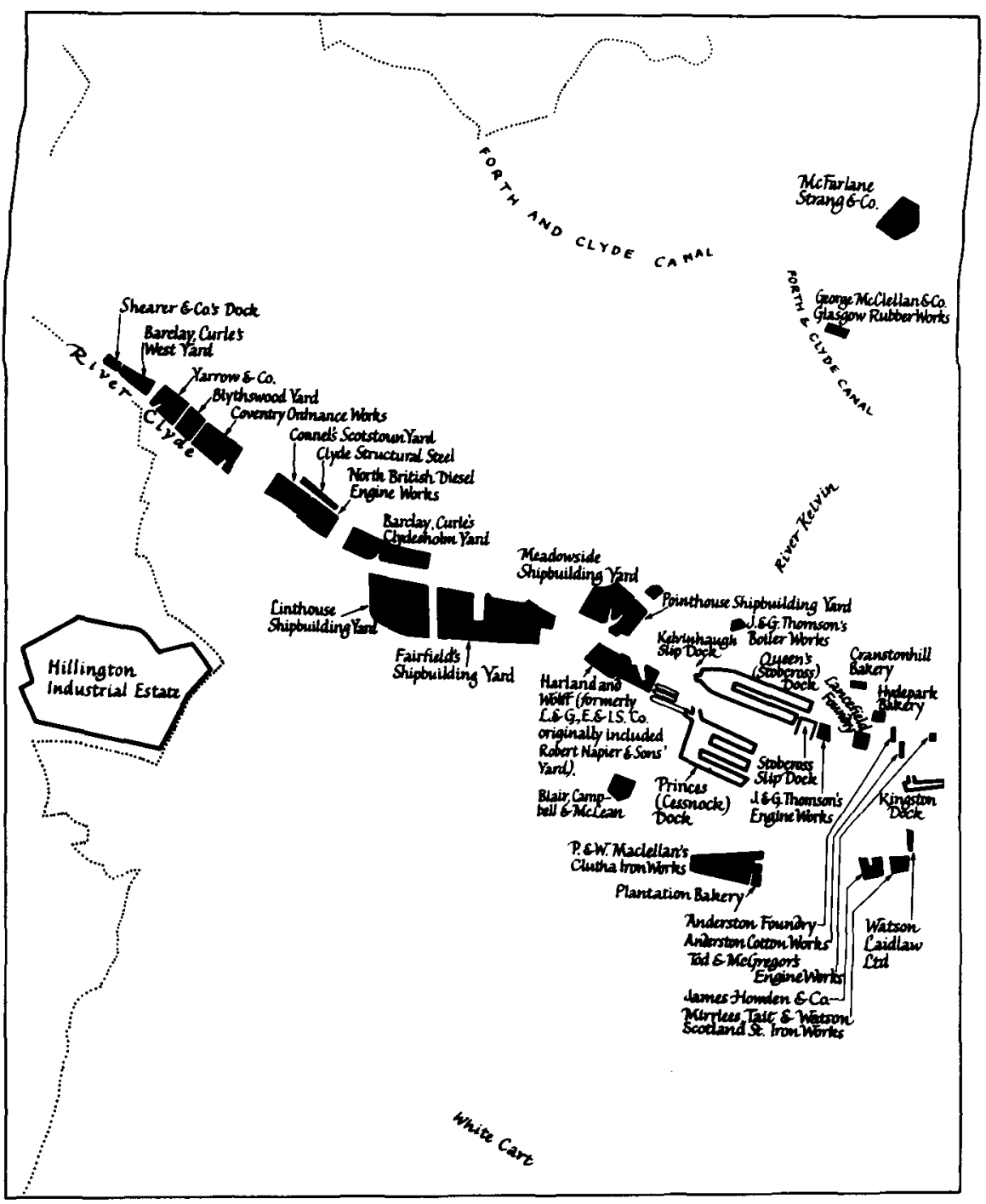

Industrial Clydeside in the twentieth century: Major workplaces around Glasgow (Courtesy of M. Moss and J. Hume) 
outlining the actual programmes undertaken and the major objectives of their designers. In each case the advent of housing investment is related to the general growth of the enterprise and the management innovations of the time.

\section{John Elder and Fairfield Shipbuilding and Engineering Co.}

The Fairfield yard of John Elder already dominated the burgh of Govan in the 1870 's and shortly afterwards was described as "the leading shipbuilding establishment in the world", holding eleven berths and employing up to seven thousand men in the shipyard and engineering works. ${ }^{49}$ Like so many other promising shipbuilders, John Elder had been trained in the service of the Napier family before assuming control of the Govan works himself. ${ }^{50}$ Following the remarkable career of Elder, his family retained an interest in the company which imported the brilliant William Pearce as naval architect after the latter's experience in the Admiralty departments. ${ }^{51}$ Such contacts proved valuable during the rapid expansion of the enterprise, securing naval orders in competition with Thames builders, and by the end of the 1870 's the Fairfield concern held fixed assets of $£ 337,000 .^{52}$

The utility of government connections continued to be recognised after the death of William Pearce in 1889, as key figures moved between the Armstrong-Vickers empire and Fairfields, and shares were exchanged with Cammell Lairds and Coventry Ordnance before $1914 .{ }^{53}$ Results could be measured in terms of the sustained prosperity of the Fairfield company for a decade after 1901 , with profits averaging $£ 110,000-190,000$ per annum. ${ }^{54}$ Only in the immediate pre-war years did many of the management problems and marketing difficulties at Coventry Ordnance begin to tell against the parent firm, which were only resolved by wartime contract expansion. ${ }^{55}$ These successes at Govan were secured by an aggressive management organisation of the yard after 1900 , with emphasis upon tight surveillance and discipline rather than investment in fresh machinery or equipment. ${ }^{56}$ 49 Robertson, "The Management of Manpower", pp. 67-71.

50 J. Napier, Life of Robert Napier (Glasgow, 1904), pp. 19-21; E. Morris, The Life of Henry Bell (Glasgow, 1844), p. 83.

51 Napier, Life of Robert Napier, pp. 149-51, 183-89; W. J. Macquorn Rankins, A Memoir of John Elder (Edinburgh, 1871), p. 3.

52 John Elder, Balance Sheet, 1878, Fairfield Papers, Strathclyde Regional Archives, Glasgow, UCS 27/1.

${ }^{53}$ The Stock Exchange Gazette, 1910, p. 1293; Scott, Vickers, op. cit., p. 91, for example of E. T. D'Eyncourt.

${ }^{54}$ Fairfield papers, Balance Sheets, UCS $25 / 1-28$, for printed accounts indicating profits.

${ }_{55}$ Ibid.; Fairfield Minutes, 1912-14, Fairfield Papers, UCS $21 / 3$, for further details.

${ }^{56}$ Fairfield Balance Sheets show capital additions varied from approximately $£ 1,450$ to $£ 53,150$, but were seldom beyond $£ 30,000$. 
The consequences included a series of bitter disputes with a variety of trades, including coppersmiths and shipwrights, particularly over the issue of supervision and discipline. Such experiences explain the notorious antagonisms between management and men which burst into life once again during the munitions crises of 1915. Even the enquiries into Clyde strikes and industrial unrest were forced to acknowledge the extraordinary resentment created by the unflinching policies of an authoritarian management. ${ }^{57}$

The labour needs of the Fairfield enterprise were great and growing after 1870 , particularly for iron-working tradesmen who were given the responsibility of negotiating the transition from iron to steel hulls during the 1880 's. Yet there is little evidence of any extensive housing provision by the employers before 1914. Although the Elders were interested enough to visit some company housing at Dumbarton in 1870 , and developed similar accident welfare schemes to those promoted by Dennys, they were not compelled to furnish accommodation for their own employees ${ }^{58}$ The reasons appear to lie in the relative efficiency of local builders and the easy access to the Govan yard from neighbouring areas. Govan and Fairfield wards were fortunate in possessing a large and steadily increasing artisan population, able to afford good tenement flats which were laid nearby the yards. This group provided a solid basis of demand upon which speculative builders like Andrew Simpson constructed Elderpark Street during the 1870 's, alongside the civic amenities endowed by the shipbuilding dynasty ${ }^{59}$ During the great housing boom of the 1890 's, larger concerns like Stewart and Co. were prepared to erect the remarkable number of 152 tenements (costing $£ 167,550$ ) on a speculative basis before the collapse of 1903-04. ${ }^{60}$ So great was the pressure on space around the works that applications were made for tenement foundations next to the shipyard walls. ${ }^{61}$ For those unable to secure such dwellings, transport was readily available in the form of the ferries bringing hundreds of men across from Partick and Govan each morning, or the trams rolling from the city centre. Although rents were still high in Govan and Partick, they were clearly not

57 North West Engineering Trades Employers' Association (hereafter NWETEA) Minutes, 20 February 1912, for pre-war coppersmiths' disputes and bitterness of management-man relations.

58 Jotting Books of William Denny, 6 January 1870, Denny Papers 3 16/1-6, for the visit of Elders to view cottages. Denny also admired the piecework system at the Fairfield Yard.

59 Govan Dean of Guild, Registers of Applications, Register, 1870, Ref. 240-300, Strathclyde Regional Archives, for some sample examples.

${ }^{60}$ Ibid.; Rodger, "Speculative Builders", pp. 236-37.

61 Govan Dean of Guild, Register, 1890, Ref. 101, for example. 
as burdensome as in Clydebank or Scotstoun, and the problem remained absolute shortages rather than spiralling rents after 1900 .

The Elders and Pearces mainly confined their municipal activities to the construction of such impressive facilities as the Pearce Institute and Elder Infirmary or Elderpark Library. ${ }^{62}$ Builders may well have been encouraged by land concessions, though it was not until the war that Fairfields even discussed the housing situation. By 1915 the position had changed quite dramatically. There was increasing pressure on the works management to improve output and discipline at the trouble-torn shipyard, as directors found government delivery dates passing without the completion of battleships ${ }^{63}$ Traditional methods of coercion were greatly increased by the legalistic penalties of the Munitions Act, though the serious shortage of skilled labour gave the men a basis for resistance which could only be broken by extraordinary regulation of the labour market. ${ }^{64}$ In this climate the supply of labour became a matter of serious strategic and political importance, as well as the precondition for the massive profitability promised by war contracts. After reviewing the possibility of purchasing local tenements or constructing emergency bungalows (probably the prefabricated type advocated by Weir), the directors resolved to convert the Pearce Institute into temporary accommodation as an immediate measure and to sanction an expenditure of $£ 10,000$ maximum on workers' dwellings. ${ }^{65}$ Although no acquisitions seem to have taken place in the difficult and charged atmosphere of 1915 , Fairfields did purchase three tenements later in the war with the eventual intention of enlarging the works through their demolition. ${ }^{66}$ By that point, the firm had returned to the profitability of the best pre-war years, and could undertake commitments which were partly deductable against Excess Profits duties. ${ }^{67}$

\section{Alexander Stephen and Sons}

The neighbouring area of Linthouse (or South Govan), saw very different housing developments from those at Fairfields. In 1870 the marine engineers and shipbuilders Alexander Stephens moved from Kelvinaugh to a new yard at Linthouse, where they employed perhaps a thousand men. ${ }^{68}$

62 The Baillie, November 1880, for a portrait of Sir William Pearce.

63 Fairfield Minutes, 15 December 1915.

64 Melling, "Non-Commissioned Officers", loc. cit.

${ }^{65}$ Fairfield Minutes, 26 March 1915.

66 Ibid., 26 June -3 August 1917.

67 Ibid., 30 October 1914 - 21 December 1917, for some indication of profitability.

68 Alexander Stephen Minutes (1900-21), 12 July 1911, Stephen Papers, University of Glasgow Deposit $412 / 1$, for their decision not to invite public subscription; Cormack,

"An Economic History", pp. 193-94. 
Considerably smaller than the Elder establishment, Stephens were an important repairing specialist with powerful family control well after the limitation of liability in 1899.69 Despite their second rank, Stephens were one of the best organised yards on the Clyde, with a systematic programme of mechanical improvements and advanced management at their works before $1914 .^{70}$ Before and during the war they remained committed to capital investment and the long-term expansion of both shipyard and repair works, including good communications systems at the workplace. ${ }^{71}$

Although Stephens remained a family concern valuing personal skills and immediate contacts with their employees, they also displayed a ruthless determination to impose management authority and to crush any organised resistance from their tradesmen. ${ }^{72}$ The family were amongst the earliest advocates of strong organisation by the shipbuilding employers, serving as leaders of trade associations and joining Pearce in the opposition to society restrictions. ${ }^{73}$ Throughout they maintained a healthy respect for the skills and ability of their craftsmen, being quick to realise the crucial importance of labour supply in negotiations with their men. ${ }^{74}$ This insight was also evident at the foundation of the new shipyard in 1870 , when one third of a thirty-acre site was allocated for housing construction and future expansion of the works. ${ }^{75}$ It is known that at least some of the tenements surrounding the yard gates were owned by the Stephens, though many of these houses might have been possessed by individual members of the dynasty rather than the partnership. The streets were certainly named after such individuals and included an impressive row of stone terrace housing suitable for foremen, draughtsmen and clerks. ${ }^{76}$ Although the land was held by the firm, it seems unlikely that hundreds of dwellings were built directly in a period of private speculative boom, and the family may well have offered space and capital on a favourable basis to such contractors which would partly explain the levels of speculative activity seen in the

69 Ibid., pp. 193-95; see Annual Trade Supplement, Glasgow Herald, 1913, for a ranking of the leading yards on the Clyde.

70 Stephen Minutes, Annual General Meeting, 8 July 1907; also 12 July 1911, for investments including an experimental tank.

71 Ibid., 31 July 1918.

72 Alexander Stephen, Letter Book No 5(1892-93), 25 December 1892, Stephen Papers 4 1/22, for firm's policy; Anon., A Shipbuilding History: Alexander Stephen \& Co. Ltd., 1750-1932 (London, 1932), p. 27.

73 J. L. Carvel, Stephens of Linthouse, 1750-1950 (Glasgow, 1950), p. 88, for Alexander Stephen's appraisal of skill and education.

74 Stephen Minutes, 2 July 1912, for example.

75 Carvel, Stephens of Linthouse, pp. 156-57.

76 Oral-history transcripts of Glasgow Rent Strike (Interview 1978), No 1, pp. 1-2; No 4, p. 4; No 6, p. 12, for some evidence. In the possession of the present author. 
whole Govan area before 1900. Whatever the degree of involvement, Stephens played a major role in the social life of the burgh by patronising educational (including technical classes) and recreational activities, culminating in the impressive projects of the post-war era. ${ }^{77}$

\section{William Denny and Brothers}

Another medium-size shipyard which specialised in a particular branch of the regional industry was the firm of William Denny and Brothers, who built river-going vessels at their Dumbarton plant. Like Stephens it remained a staunch family enterprise from its formation in 1844 to its eventual collapse more than a century later. Shipbuilding on the Leven developed somewhat later than at Clydeside, though from the 1850's the advance was so rapid that Dumbarton's population tripled in five decades. ${ }^{78}$ Of the six shipbuilders employing perhaps 2,500 men in all at the middle of the nineteenth century, Dennys was already the largest with assets approaching $£ 137,000$ before $1860 .{ }^{79}$ Also like Stephens and Elders, the Denny clan built up their firm by a combination of progressive technology and a systematic organisation of the workplace, which included tight control of materials used and piecework systems for wood-working trades. ${ }^{80}$ Without the advantages of naval construction, Dennys improved their marketing scope by sustained contact with shipping interests which improved their order lists. ${ }^{81}$. The decade after 1875 proved to be decisive, with a new tidal basin acquired and the rapid growth of a concern employing three thousand men under the dynamic management of William Denny III. ${ }^{82}$ Whilst not one of the largest employers before 1914, Dennys were undoubtedly among the more successful enterprises, and were able to exploit their established policies on working methods during the pressures of wartime production with remarkably little disruption in the yard..$^{83}$ The foundation for this record of efficiency and profitability

77 The Linthouse Magazine, September 1920; Anon., A Shipbuilding History, op. cit., pp. 158-63.

${ }_{78}$ B. D. Osborne, “Dumbarton Shipbuilders and Workers' Housing, 1850-1900", in: Scottish Industrial History, III (1980), p. 2.

${ }^{79}$ Ibid., pp. 2-3; P. L. Robertson, "Shipping and Shipbuilding: The Case of William Denny and Brothers", in: Business History, XVI (1974), pp. 38-39.

80 Jotting Books of William Denny, 2 August 1869; A. B. Bruce, Life of William Denny (London, 1889), pp. 86-89.

81 Robertson, "Shipping and Shipbuilding", pp. 42-43.

82 Cormack, "An Economic History", p. 67.

83 Royal Commission on the Poor Laws and Relief of Distress [Cd 4499], Appendices to Minutes of Evidence (1909-10), Employers' Replies, Archibald Denny, Reply No 1; see K. Woodroofe, "The Royal Commission on the Poor Laws, 1905-09", in: "International Review of Social History, XXII (1977), pp. 137-64, for background to the report itself. 
had been laid with the new Leven Shipyard after 1864, which gave Dennys an excellent location on the Leven for organising the construction and launching of the completed hulls. The organising genius of the family was not completely lost with William III's suicide during the 1880's, and both Peter and Archibald Denny effectively coupled detailed planning at work with a strong sense of social responsibility in the town. ${ }^{84}$

Similar acumen was displayed in the acquisition of a labour-force itself, as Dennys faced (along with local rivals) problems of rapid geographical mobility amongst a working class in search of higher wages and better accommodation during the mid-century years. ${ }^{85}$ The first effort to create a steady core of key workers was made in the 1850's, when tenement blocks for over two hundred families were constructed at what became Dennystoun. ${ }^{86}$ Work began on the second main phase of housing, at Newtown, before the Leven Shipyard was complete, with Dennys providing only a handful of cottages for favoured employees and feuing out the remaining land on favourable terms to other builders. ${ }^{87}$ Many loans were advanced on a mortgage basis at low rates of interest, mostly to wood-working tradesmen who appear to have participated in the construction of the housing during the 1860 's ${ }^{88}$ The amounts varied from $£ 200$ to $£ 600$, mainly to the key trades who manned Leven Shipyard, whilst the original brick cottages were sold off to selected workers at $£ 130$ each - again occupied by skilled workers and their supervisors in wood working and engineering trades. ${ }^{89}$ Certain workers took the opportunity to harvest their own capital, particularly supervisors who purchased more than one cottage and undoubtedly rented them out to journeymen. It seems that one foreman joiner who suggested the extension of piecework at the yard was amongst this minority enjoying the patronage of Denny management. ${ }^{90}$

There were also serious efforts to promote the acceptable artisan values of thrift and sobriety amongst workmen in this booming town, as

84 Jotting Books of William Denny, 30 December 1869, for great soirée with workmen; ibid., March 1873.

${ }^{85}$ Osborne, "Dumbarton Shipbuilders and Workers' Housing", p. 9.

86 Ibid., p. 4. It should be noted that the housing was valued at $£ 24,000$ at a period when total assets of Denny Brothers were less than $£ 140,000$.

87 Ibid., p. 6, for the 43 tenements planned at Newtown

88 William Dennys, Workmen's Housing Ledger, Denny Papers $326 / 5$, for bond agreements with workmen.

89 Ibid.; Archibald Denny, Replies, loc. cit., No 9.

90 Workmen's Housing Ledger. Of the nineteen agreements recorded for brick cottages, 8 were with carpenters, 7 with joiners, 1 with a riveter, blacksmith, clerk and labourer respectively. One foreman joiner, Rankine, bought three cottages and repaid almost $\$ 400$ of his debt very quickly. This individual appears to be the one referred to in the Denny Jotting Books. 
generations of Denny sponsored friendly societies and accident schemes for their employees. ${ }^{91}$ In the sphere of housing, this took the form of support for the terminating and permanent building societies operating from the 1870 's. Peter Denny was particularly active in promoting the societies at both the Newtown and much larger Knoxland scheme in the 1870's and 1880's. ${ }^{92}$ The emphasis on home ownership and self-help led to a situation described by Archibald Denny before 1914, where Dumbarton was "a town of almost 4,500 inhabitants ... the houses being almost entirely owned by the workmen", whilst their employers had been enabled to devote their scarce capital to the "additional plant and increased facilities" which ensured continued employment amongst a property-owning artisanate. ${ }^{93}$ One of the incidental benefits was the relative absence of the serious tenant unrest which had marked the shortages of the 1880's at Dumbarton, and were to dominate the first two decades of the century elsewhere in west Scotland.

\section{Alfred Yarrow and Co.}

By the end of the nineteenth century, Fairfields, Stephens and Dennys were all well established as shipbuilding yards with a range of specialisms in the industry. Before 1914 there were to be at least three major additions to the region's ranks, as Clydeside continued to rise in importance and led the movement towards the integration of steel, arms and ships at this period. The arrival of Alfred Yarrow and Co. at Scotstoun, above Partick and Whiteinch, in 1906 serves as an epilogue to the protracted eclipse of the Thames as a shipbuilding centre and the ascendancy of Northern iron workers. The economic advantages of Clydeside over Poplar were apparent when the firm found it could purchase land at $£ 50$ an acre, after paying twice that amount to rent the equivalent space in London. ${ }^{94}$ Yarrows also used the opportunity to completely reorganise their operations in the yard, which were designed for the production of fast steam launches (including naval pursuit ships) and yachts for the wealthy of Edwardian society. ${ }^{95}$

This thriving concern had again been built into an efficient mediumsized enterprise through determined marketing policies and a ruthless opposition to trade societies. They had made a notorious contribution to the 1897 troubles in the capital by housing blackleg labour in a floating

91 Osborne, "Dumbarton Shipbuilders and Workers' Housing", p. 7.

92 Ibid., p. 8.

${ }_{93}$ Archibald Denny, Replies, No 9.

94 Cormack, "An Economic History", p. 83.

95 Pollard, "The Decline of Shipbuilding on the Thames", p. 84. By 1913, Yarrows were amongst the leading twenty shipbuilders in Scotland. 
Thames barge, closely guarded against the demonstrations of local shipwrights. Yarrows were also bitterly antagonistic to the Labour administration at Poplar's local government at the time of their departure for Scotland, which helped to harden their resolve on a Scottish base. ${ }^{96}$ The management imported its policies along with a solid core of loyal London labour to the new works at Clydeside, and was soon embroiled in a number of disputes over working methods and payments systems. There finally erupted in the last year of war a direct confrontation over these practices, with the Joiners' Society threatening to call out its 127,000 membership in protest at the yard bonus scheme, officials complaining that

the Society had no antipathy against the firm but against the bonus system which their Joiners worked. [...] Messrs Yarrow came from London to Glasgow as a "black listed" or "Non-Union" firm. [...] all the men in the shop were not asked to work bonus nor were they all put on the system, it being given only to a favoured few. ${ }^{97}$

Although the unions denied any specific resentment against the Poplar capitalists, it is clear that Yarrows were bitterly disliked on Clydeside for their anti-union strategies. One reason for the interest Yarrows expressed in technical education and workplace innovations after 1900 was almost certainly their uneasiness at continuing trade-society regulation of apprenticeship and training at their yards. ${ }^{98}$

These considerations contributed to the decision of Alfred Yarrow to bring hundreds of loyal employees north when he moved to Scotstoun; men who had already weathered to conflicts of the previous decade and whose skills provided a solid workforce for the renewed operations. ${ }^{99}$ Consequently the company undertook the completion of 350 brick cottages (in sharp contrast to the surrounding stone tenements), in a style familiar to the immigrant workers and nearby the growing shipyard. ${ }^{100}$ The employers seem to have directly intervened in the housing market, and even allowing for the savings on land and building materials the cost must have reached many thousands of pounds. Allowing for a low estimate of even $£ 200$ per cottage, the investment would have represented $£ 70,000$ in all before

${ }_{96}$ R. O. Clarke, "The Dispute in the British Engineering Industry, 1897-98: An Evaluation", in: Economica, XXIV (1957), p. 133; Cormack, "An Economic History", pp. 202-03.

${ }^{97}$ Clyde Shipbuilders' Assicuatuib, Minutes, 4 September 1918, Strathclyde Regional Archives.

${ }_{98}$ P. L. Robertson, "Technical Education in the British Shipbuilding and Marine Engineering Industries, 1863-1914", in: Economic History Review, Second Series, XXVII (1974), p. 229.

99 A. Borthwick, Alfred Yarrow and Company: The First 100 Years (Glasgow, 1965),p.81.

${ }^{100}$ Sir Eric Yarrow, letter and notes to present author, 1976. 
1914. ${ }^{101}$ Yarrows do not appear to have contemplated building via incentives to local speculative firms or by utility societies, but to have expressed a commitment to shape and sustain the environment in which their employees lived and worked.

\section{Clydebank Shipbuilding and Engineering Co. and John Brown}

Another recent arrival at the Clyde was the great enterprise of John Browns of Sheffield, absorbing the Thomson shipyard in their integration of steel, shipbuilding and armaments interests. The partnership of James and George Thomson had transferred their operations from Govan to a site beyond Scotstoun at Clydebank, during the 1870's. ${ }^{102}$ As a rising shipbuilding family, the Thomsons acquired thirty acres of land with well over a thousand feet of water frontage at this isolated stretch of the Clyde. ${ }^{103}$ With the arrival of the Singer Company at Clydebank from Bridgeton in 1883, there were tremendous pressures on available housing at this shipyard burgh. So acute were the shortages that even in 1915 it was estimated that sixteen thousand men travelled to their work at Clydebank from Glasgow and other areas. ${ }^{104}$

After the formation of the Clydebank Shipbuilding and Engineering Company by the Thomson interests in 1890 , the firm surged ahead with capital assets valued at more than $£ 350,000$ and reaching almost $£ 600,000$ in real terms by the close of the decade. ${ }^{105}$ Effective marketing entailed the cultivation of family connexions with the Cunard Company at Liverpool, and the aggressive pursuit of naval orders. ${ }^{106}$ Thomsons ensured their reputation by completing HMS Terrible for the Admiralty in a record time of fourteen months, and in 1899 was held to be one of the "best equipped and most successful shipyards and engineering works in the United Kingdom". ${ }^{107}$ Offering a specialism in fast torpedo boats as well as large passenger or merchant vessels, Thomsons followed a policy of renewed

101 The Yarrow records were, according to the company, lost during the Blitz. If we assume a cost of $£ 200$ per cottage, this would bring total expenditure to $£ 70,000$.

102 B. M. White, "The Inevitable Ship" (MA dissertation Glasgow, 1974), pp. 23-25; Cormack, "An Economic History", p. 194.

${ }^{103}$ Clydebank Shipbuilding and Engineering Company (hereafter CSEC), Title Deeds of Works and Workmen's Houses, Scottish Record Office, Edinburgh, pp. 1-3. Courtesy of Mr J. Sime.

${ }^{104}$ Melling, "Clydeside Housing", loc. cit., for details of this at the 1915 Rents Enquiry. 105 Cormack, "An Economic History", pp. 70-71.

106 John Browns Minutes, 1899-1910, Upper Clyde Shipbuilders Papers (hereafter UCS) 1 1/13, University of Glasgow Deposit, 30 August and 16 December 1890, 31 March 1891 .

107 Sir Allan Grant, Steel and Ships: The History of John Brown's (London, 1950), pp. $37,40-44$. 
investment after 1896 and added impressive new slipways as well as engine works to their Clydebank yard. ${ }^{108}$

Profitability was sustained rather than remarkable during the 1890's, falling to a substantial loss in 1894 but reviving to produce record returns the next year. ${ }^{109}$ It was at this stage that John Browns of the Sheffield Atlas Works became interested in the Clydebank firm, acquiring a significant share in 1896 and taking over the enterprise from 1899.110 Browns's manufacture of reinforced steel plates under Krupp-design specifications for battleship armour gave them a direct interest in the market for naval armaments and, like other great concerns (including Vickers and Cammells), they penetrated the shipbuilding sector to guarantee production flows. ${ }^{111}$ After arriving at Clydebank, the junior board set about increasing capital investment in both shipyard and engineering works, coupled with a rigorous organisation of working processes at the plant. ${ }^{112}$ As in Stephens, the internal communications were improved by massive expenditure on docks, railways and general equipment after 1904, emphasising the integration of units at the Clydebank site. ${ }^{113}$

This was accompanied by a firm management policy on workplace disputes, as Brown management sought to establish sharp distinctions in the correct order of hierarchy and responsibility. At a time of rapid technological change in the design and production of battleships, new working methods and modifications were constantly required and fresh precedents of trade rights established. Demarcation disputes were almost endemic at periods of mounting unemployment, as societies fought to maintain their right to particular areas of work. Clydebank management insisted that they would recognise only general customs and practices, reserving the ability to direct tradesmen to different jobs and decide on interchangeability of work. ${ }^{114}$ Such antagonisms caused unrest amongst the lower grades of supervisory workers, exacerbated by the erratic undulations of the trade

108 CSEC. Board Papers, "Estimated Profit on Work in Progress at 31st March 1895", UCS $15 / 2$.

109 CSEC, Directors' Minutes (1891-99), UCS 1/1. Figures included show that net profits ranged from $£ 24,500$ (with one year of loss at $£ 44,250$ ) to $£ 139,500$ in 1898 .

110 Ch. Erickson, British Industrialists: Steel and Hosiery (Cambridge, 1959), p. 208.

111 Grant, Steel and Ships, op. cit., pp. 36-37; H. W. Macrosty, The Trust Movement in British Industry (London, 1907), pp. 43-45.

112 CSEC and John Brown, Balance Sheets and Annual General Meeting Agendae (1895-1919), UCS 14/1-24. Capital additions are given in detailed appendices.

113 Capital additions, ibid., which include figures for investment in equipment, docks, railways and other plant. Total additions varied between $£ 6,542$ and $£ 68,791$ in the years $1904-12$, but in five years were above $£ 54,000$.

114 NWETEA Minutes, 8 July 1902, for the statement by John Browns to the North West Engineering Employers on this issue. 
cycle before 1914, but only boiled over during the war itself. After the tacit agreements on mercantile dilution after autumn 1916 there remained powerful local resistance to the use of pneumatic tools, and Browns discovered that their only effective reply was the importation of outside labour. ${ }^{115}$ Later in the war the same management complained of persistent political agitation in the yard and obstructive tactics by workers restricting output, Browns arguing for harsh legal penalties against activists encouraging unofficial stoppages. ${ }^{116}$

Throughout the decades of growth from the 1880's to 1920, housing remained an important issue for a firm so heavily dependent on skilled labour. Within the first decade of establishing operations, Thomsons undertook the construction of at least two tenement blocks which included shops prohibited from alcohol sales or any public pollution. ${ }^{117}$ In 1885 the Thomson interests acquired a further five thousand yards of space, on the understanding that they would build a further three blocks of solid tenements. ${ }^{118}$ Some of this activity may have taken the form of incentives to speculative builders prominent during the 1870 's, but by 1890 the new company valued its housing at $£ 22,750$ amongst total assets of $£ 351,000{ }^{119}$ During the important year of 1896 the directors again discussed the question of labour shortages, and after considering direct construction decided on offering ground to local builders on favourable terms (even extending to financial assistance). ${ }^{120} \mathrm{With}$ this end in view, the Clydebank employers purchased another twenty-five acres of ground on the river side of Dumbarton Road before considering offers from local contractors. ${ }^{121}$ When valuing the whole concern in 1899, a surveyor found an almost new tenement - suggesting further building and purchase at this period. ${ }^{122}$

Against a background of mounting conflict over managerial prerogatives and technical change in the engineering and shipbuilding sectors,

115 John Browns to Ministry of Munitions, unsigned letter of 5 October 1916, confidential papers and letters in UCS $122 / 4$.

116 Ibid.

117 CSEC, Title Deeds, pp. 65-69, for contract dated 8th March 1883, and p. 75 for map of same.

118 Ibid., pp. 91-93, giving details of contract of 2 July 1885; "The said tenements shall contain houses of not less than one room and kitchen and no dwelling house shall be let for the purpose of being occupied by more than one family and no house [. . ] shall be erected on the back ground."

119 CSEC, Balance Sheets, including figures enclosed in Minutes.

120 CSEC Minutes, 25 February - 10 March 1896.

121 CSEC, Title Deeds, pp. 105-17, for contract of 11 May 1897; Minutes, 24 August 1897.

122 CSEC, "Surveyor's Report" (1899), in Progress Reports, UCS 1 5/2. There were at least four three-storey tenement blocks in Union Place, all apparently of recent origins. 
the directors also reviewed the needs of their supervisory employees in 1897. They allocated ground to the east of Clydebank yard for cottage building, clearly distinguished from the tenement property inhabited by workmen. ${ }^{123}$ At the transfer of assets to John Browns in 1899, these and other dwellings were involved in a complicated series of transactions when Thomson interests apparently retained housing in their personal possession. ${ }^{124}$ The first year of Brown control included sizeable additions to housing, though the stock was consolidated until further initiatives in 1902. ${ }^{125}$ After another local builder approached the firm to develop ground nearby the yard, the new directors decided to purchase his with the intention of constructing housing for their principal supervisors and improving management accommodation. ${ }^{126}$ Such projects provided subsidised facilities for key workers, but did little to ease the growing housing pressures at Clydebank after 1905, with Browns offering travel and time allowances to secure the necessary labour from outside the burgh. With the acceleration of naval building and the great pre-war boom in merchant orders, the situation became almost intolerable. Shipyard management identified the problem with considerable succinctness when informing the board in 1914:

As regards the Ironworkers, we seem able to get altogether from 2,400 to 2,500 men, but cannot exceed it owing to constant wastage of men leaving us to Govan, Dumbarton and Partick, where they can live near their work; if we could only have kept our numbers at $10 \%$ above this [ . . ] we could not only keep on the right side of the line in our Shipyard Charges [. . .] but also we could come nearer to Government delivery requirements. [...] At present every available house in Clydebank is occupied and rents are from $10 \%$ to $20 \%$ dearer than in Govan. The building trade is at present stagnant, and there is nothing for it but to arrange with a Builder ourselves. ${ }^{127}$

This memorandum proposed the construction of 112 dwellings at a cost of $£ 71,500$ near the West Yard, estimating a return of 4-5\% from rental income on capital invested. ${ }^{128}$ The document also made it clear that there were numerous strategic advantages in remedying a situation where supervisors and journeymen were crowded together under the difficult

123 CSEC Minutes, 24 August 1897.

124 CSEC, Balance Sheets, which indicate a fall in housing valuation from $£ 21,650$ to $£ 17,158$, which itself suggests either sales or possibly transfer to private holding by the Thomson family.

125 Ibid., where additions of $£ 4,200$ brought the full valuation to almost $£ 33,000$.

126 John Browns Minutes, 22 October and 19 November 1902, 18 March 1903. Progress Reports, No 10 (1902), also gives estimation.

127 Shipyard Manager, Bell, "Memorandum on the Shortage of Ironworkers" (1914), UCS $123 / 3$.

128 Ibid. 
conditions of pre-war housing. ${ }^{129}$ Management suggested that there should be a radical reorganisation of dwellings to resolve the situation, arguing that

a question which is causing us grave concern is that of our Ironworker, Carpenter and Joiner Underforemen. [.. .] Owing to the great fluctuations in the amount of our work [...] the larger number of these men seem reluctant to throw themselves heartily on the side of their Employers [...] when they may be disrated and have to work as mates with the men at present under them and with whom they live in adjacent flats. [...] The Management at Clydebank strongly recommend housing these men in [...] self contained flats [...] very near to the Yard, but entirely devoted to cottages and separated by the Railway from the working-men's tenements. ${ }^{130}$

The directors agreed to finance workmen's tenements, but were less persuaded of the supervisory difficulties which their management complained about, until the sudden outbreak of war swept Clydebank into a fresh housing crisis as thousands enlisted and immigrants flooded into West Scotland to replace them.

Significant advances were not seen until 1916, with substantial additions near the yard including special dwellings for shipbuilding foremen. In the next three years Browns spent almost $£ 140,000$ on housing, with supervisory accommodation alone costing $£ 12,500 .{ }^{131}$ The motivation of the employers was again more complicated than a simple reflex to housing shortages, given the intensity of industrial conflict and social protest in these years. Despite the spiralling building costs and earlier restriction on working-class rents and mortgage bonds, Browns were prepared to undertake a massive commitment only because of the prospects of even larger profits from government contracts. Housing was also a powerful lever in the struggle with overcrowded labour over dilution agreements after autumn 1916, restoring to employers some degree of labour-market regulation. As the company explained to the Ministry of Munitions in October 1916 ,

With reference to the extension of dilution which is really one of the most pressing problems of the day, we have found ourselves very handicapped indeed in the development of pneumatic rivetting [...] As we found it impossible to initiate pneumatic rivetting in those Works with local labour, we looked elsewhere for suitable recruits [and] these men would only come North on the strict assurance that we could put up houses for them. ${ }^{132}$

131 John Browns, Balance Sheets and capital additions entries.

132 John Browns to Ministry of Munitions, 5 October 1916. 
The judgement of the firm seems to have been vindicated by the substantial profits made at Browns thereafter, even though the management was still complaining bitterly of industrial "syndicalists" and socialists during the year before Armistice. ${ }^{133}$ Housing was partly deductable against Excess Profits Duty levied by the government, with the Munitions Ministry strongly advocating such schemes in heavy industry, hence the optimism expressed by the company during the completion of housing after the end of the war. Such urban amenities as social clubs, bowling greens and local hospitals continued to be patronised by the employers as natural complements to the improved dwellings. ${ }^{134}$

\section{William Beardmore and Co.}

In the years before the outbreak of war, the firm of William Beardmore and Co. seemed to epitomise the growing convergence of steel, shipbuilding, engineering and armaments production on Clydeside. Like so many of his contemporaries, the founder of the iron and steel empire based on Parkhead Forge had been trained by the Napiers. ${ }^{135}$ During the late nineteenth century Beardmores became the largest British manufacturer of the armour plating used in naval construction, and the expansion into armaments and shipbuilding production after 1900 appeared a logical development. ${ }^{136}$ This step soon created problems for the second William Beardmore, whose personal style of management veered from the autocratic to the idiosyncratic. A persistent advocate of technical innovation and systematic training, Beardmore threw his resources into sudden spurts of expansion, which led to liquidity crises as the firm over-reached itself. ${ }^{137}$ It was the massive investment programme following the limitation of liability in 1901 that created the situation where Beardmore was forced to accept the "semi-merger" with Vickers in the next year. Whilst continuing to support Beardmores (holding half the voting shares), the great VickersArmstrong interests actually feared the eventual success and independence of a resurgent Beardmore in the competitive climate before war was

133 John Browns to Ministry of Munitions (unsigned), February 1918, UCS 1 58/1: "only the enactment of a penal clause is likely to have a deterrent effect on 'industrial reformers'."

134 John Browns Minutes, 21 December 1906 - 28 September 1908; Oral-history transcripts on Industrial Supervision (Interviews 1981), No 3, p. 23.

135 H. Hamilton, The Industrial Revolution in Scotland (Oxford, 1932), p. 108.

136 Scott, Vickers, op. cit., p. 49, J. Trebilcock, The Vickers Brothers (London, 1975), p. 39.

${ }^{137}$ Sir William Beardmore, "The Influence of Scientific Research on Industry", in: Transactions of the Iron and Steel Institute (May 1916), reprint in Beardmore Papers, University of Glasgow Deposit 100, courtesy of Mr M. Moss. 
declared. ${ }^{138}$ This feverish expansion and accumulation increased during the years up to 1921, assisted by the placing of influential businessmen in the highest organs of government. ${ }^{139}$ Critics documented the vast range of interests and activities undertaken by the armaments magnates at this time, including links with financial and investment trusts which bore comparison with the cartels of imperial Germany. ${ }^{140}$

These developments involved a series of new investments within Beardmores, as the Parkhead Forge foundries and engineering shops were expanded and a new steel plant at Mossend acquired after 1905. The most significant project took place in Dalmuir, below Clydebank in the empty stretch of land before Old Kilpatrick and Dumbarton itself. Here a great new shipyard and engine works was laid in the expectation of large naval orders, which never materialised before 1914. The scale of this addition (completed mainly in 1902-06), can be gauged by noting the shift in the axis of investment, from the point where in 1901 well over four fifths of Beardmore resources was channelled into Parkhead rolling mill and forge shops, to the situation a decade later when Dalmuir alone claimed $28 \%$ of total expenditure on capital goods and equipment.

Such an ambitious programme of expansion was not crowned by sustained profitability in peacetime production, however, and despite continuing vitality at Parkhead the Dalmuir plant made serious losses most years after 1905, whilst Mossend proved only marginally profitable at the same period. ${ }^{141}$ The virtual exclusion of Beardmores from much of the lucrative naval and arms work, inevitable in view of their late arrival and the attitude of Armstrongs and Vickers, certainly hindered progress in the leaner years before the war. Yet there were also serious organisational and management difficulties at Dalmuir, with bitter disputes between trade societies as each sought to assert working practices and also with shipyard managers attempting to impress the more advanced techniques and payment systems on the local workforce. ${ }^{142}$ The coming of war seemed to provide the awaited opportunity for radical innovation and rationalisation,

138 Scott, Vickers, pp. 49-56, and p. 92 for letter of Albert Vickers to Sir Andrew Noble of Armstrongs.

${ }^{139} \mathrm{Ch}$. Addison, Four and a Half Years, I (1934), pp. 89-99, 104, for events covering 4-21 June, 7 July 1915.

140 J. M. Hay, The Beardmore-Vickers Octopus (Socialist Information and Research Bureau, Glasgow, 1920), p. 3 and passim; cf. G. D. Feldman and U. Nocken, "Trade Associations and Economic Power", in: Business History Review, XLIX (1975), pp. 417-19, for the contemporary German context.

${ }_{141}$ William Beardmores, Balance Sheets and detailed appendices, University of Glasgow Deposit 1008.

142 NWETEA Minutes, 22 August 1911, for a characteristic dispute between the engineers of ASE and the Drillers, the latter being organised by the Shipwrights. 
as Beardmore himself argued to his fellow employers. ${ }^{143}$ Particular emphasis was placed on the payment systems which had provoked such controversy before 1914, and shortly after its outbreak the ASE was locked in struggle with Beardmores over a machine-shop scheme. ${ }^{144}$ Only by relentless pressure were the managers successful in introducing premium payments, and towards the end of 1916 the firm was able to report that they were victorious in "getting about 1,600 men to work the Premium Bonus System and that if the Premium Bonus System were stopped they would require about 3,000 men to do the work now performed by 1,600 men on Premium Bonus". ${ }^{145}$ Such techniques helped the company to achieve its quite phenomenal levels of profitability during the war, converting the serious losses at Dalmuir and Mossend into net profits reaching hundreds of thousands of pounds. ${ }^{146}$ Whatever concessions were made to labour in the arrangement of dilution, it was with this massive rate of accumulation in view that industrialists negotiated.

The provision of housing followed closely the contours of economic transformation at Beardmores during the first two decades of the twentieth century. Accommodation was clearly a fundamental concern in the planning of the integrated operations after 1900, the limitation of liability providing some of the resources for a housing project directly designed by the expanding firm itself. At its formation in 1901, the Beardmore company held a small amount of terrace property near its Parkhead nucleus, purchasing more before 1906. It is possible that Beardmore maintained a certain amount in his personal control after the intervention of outside interests, though the enterprise itself only became a significant landlord on the acquisition of the Mossend Works, with its 174 cottages modernised before the war. ${ }^{147}$ The Dalmuir housing programme was one of the most impressive examples of industrial housing in West Scotland during this period. Work began on tenement property in 1905, before the yard itself was complete, and the first phase was finished within four years. Over $£ 27,000$ was invested in good-quality dwellings for a core of the workforce, and expensive villas were purchased for managerial grades or officials at the same time. Beardmores appear to have arranged construction directly with a variety of contractors, directed by one general builder who absorbed much of the capital advanced by the shipbuilders as pro-

143 Beardmore, "The Influence of Scientific Research".

144 NWETEA Minutes, 22 December 1914; History of the Ministry of Munitions (London, 1920), V, Pt I, p. 123.

145 NWETEA Minutes, 5 February 1917.

146 Beardmores, Balance Sheets (1914-18), for performance of the enterprise during war.

147 Ibid., see Table 2 below; Mossend modernisation alone cost an estimated £2,697. 
gress was made on each section. ${ }^{148}$ By the outbreak of war the firm had spent $£ 44,000$ on the construction and modernisation of company dwellings, mostly at Dalmuir and Mossend.

Beardmores initiated plans for a second great phase of building at their Clydeside yard well before the outbreak of war threatened. Earlier in 1914 the directors took the remarkable step of sponsoring an independent estate company to arrange for the building and letting of dwellings at Dalmuir. ${ }^{149}$ The Dalmuir and West Scotland Estates Company was apparently created to take advantage of the incentives offered under national housing legislation since 1890 (and particularly since 1909), to arrange housebuilding on an autonomous basis and avoid committing industrial capital to heavy fixed investment. ${ }^{150}$ Estate directors intended to raise loans from the Public Works Loan Commission at a low interest of $3.5 \%$ and secure further capital at $5.5 \%$ from an Edinburgh Investment Association. ${ }^{151}$ Beardmore control was quickly demonstrated on the outbreak of war, throwing plans into disarray, and with the entrepreneur insisting on firm estimates and returns before transferring the land to his protégé directors. Progress on the planned 33 tenements waited until the immediate crisis passed, and during the troubled spring of 1915 Beardmore decided to curtail the autonomy of his Estates Company and seek direct government assistance in the meeting of delivery dates. ${ }^{152}$ With the shortages of labour, rising costs (including the increase of Public Works Loan Commission interest, along with general government rates) and new estimates of $£ 57,000$ for completion of housing the building began. ${ }^{153}$ Having attracted a direct loan of $£ 150,000$ from the War Office, Beardmores pressed ahead with plans for further tenements in streets named after contemporary generals (no doubt to inspire the civilian workforce). ${ }^{154}$ As industrial conflicts and tenant movements spread across Clydeside during the autumn of 1915, the Estates Company were completing 230 dwellings with another 108 planned. ${ }^{155}$ The creation of a ready pool of labour during these days of general unrest, mobility and resistance to munitions restrictions was clearly vital to the Dalmuir management.

\footnotetext{
148 Ibid., for the figure of $£ 27,123$; "The Tower" at Dalmuir cost $£ 1,900$, for example.

149 The Dalmuir and West of Scotland Estate Company, Minute Book No 1 (1914-57), University of Glasgow Deposit 100 2, 9 July 1914.

${ }^{150}$ Ibid., for details of Public Works Loan Commission advance; cf. Swenarton, Homes Fit for Heroes, pp. 31-32, for legislative facilities.

151 Dalmuir and West Scotland Estates Minutes, 9 July 1914.

152 Ibid., 17 September 1914 - 13 April 1915.

153 Ibid., 13 April 1915, where an estimated cost of $£ 56,905$ was provided.

154 Ibid., 27 July. The loans were apparently transacted by the parent company, though legal and administrative functions remained with the Estate Company.

155 Ibid., 15 December; Glasgow Herald 16 October.
} 
This impetus continued during the struggles over mercantile dilution and wage demands in the autumn and winter of 1916, and by early next year the Estates Company was well into its second stage of wartime housebuilding, with plans prepared for a third phase of thirty tenements costing another $£ 60,000 .{ }^{156}$ The relentlessly optimistic Beardmore projected housing development into the post-war years of expected prosperity, though the spiralling costs of 1918-20 and the rapid decline of production thereafter marked the end of Beardmore schemes. ${ }^{157}$ By this point there had also been impressive housing additions at the other Beardmore plants, involving an even closer relationship with State agencies at Mossend, Cambuslang and Carmyle. ${ }^{158}$ In the hostel arrangements at Airdrie the firm shared responsibility for housing as well as munitions production directly with the government itself. ${ }^{159}$ Over the five years to 1919 Beardmore could claim a massive private commitment of almost $£ 168,500$ to the housing of their workforce, much of which was again liable for deduction against Excess Profits taxes levied by a sympathetic State.

The arrangements for letting and selling these dwellings were also made with a clear perception of labour requirements and an awareness of social conflict. Favoured individuals were allowed to purchase their dwellings from the company, frequently with as little as $£ 20$ deposit and on reasonable mortgage terms. ${ }^{160}$ Some of the more expansive villa properties were administered via a legal trust, which permitted the extension of good housing to management grades with few financial complications. ${ }^{161}$ The creation of the Estates Company possessed similar advantages in removing immediate responsibility for tenements from the firm, whilst ensuring Beardmore workers received preferential treatment. Benefits in the shape of securing a loyal workforce, at the same time that the neighbouring John

156 Dalmuir and West Scotland Estates Minutes, 17 January - 19 June 1917.

157 Ibid., 2 August 1917 - 22 June 1918, 3 July 1919. The building programme ended effectively in autumn of 1919. See P. L. Payne, "Rationality and Personality: A Study of Mergers in the Scottish Iron and Steel Industry", in: Business History, XIX (1977), p. 167 and passim for the subsequent ills of the industry.

${ }_{158}$ History of the Ministry of Munitions, V, Pt V, pp. 79-82, for a discussion of Beardmores, along with John Browns, Colvilles, Russells, Singers and Stewart and Lloyds. The last employers went on to found the "new" industrial town of Corby in the inter-war period.

159 Ibid.

160 The case of William Noble, who placed a $£ 20$ deposit for a dwelling at South View, Dalmuir, as recorded in Beardmore Balance Sheet for 1910.

161 B. Elliot and D. McCrone, "Landlords in Edinburgh: Some Preliminary Findings", in: Sociological Review, XXIII (1975), for a discussion of the complexities of property relations; also Rules of the Provident Property Investment Company, Miscellaneous Housing Papers, University of Glasgow Deposit $80 \mathrm{l} / \mathrm{l}$, for one investment concern. 
Brown management was considering housing commitments, must also have weighed with Beardmores at this boom period. Labour difficulties were certainly to the fore when Beardmore made the unpopular decision to import 150 tradesmen from England in 1915, when bitter controversy raged over W. D. Weir's criticisms of Scottish workers and his lucrative offers to Canadian workmen willing to accept machine methods. ${ }^{162}$

It was with industrial unrest and rent strikes in view, which had been a prominent aspect of Parkhead and Dalmuir struggles throughout the autumn and winter of 1915-16, that the Estates directors considered the terms of letting in 1916. ${ }^{163}$ They proposed that letting agreements should provide a clause empowering the factor to "eject tennents [sic] who cease to be employed by Messrs William Beardmore", and were aggrieved when legal counsel advised against such a move (no doubt with the unhappy judicial experiences of 1915 in mind). ${ }^{164}$ The directors retorted somewhat drily that they hoped their lawyers would not expect full commission where tenants refused payment and could not be prosecuted in the Sheriff Court. ${ }^{165}$ At the same time, Beardmores appear to have adopted a fairly lenient and flexible housing policy during the first two years of war, reflected in their falling rental income. Some of this may have been due to the loss of adult males to the fighting front, with concessions to dependent families, though in other cases low rents were probably used to attract skilled tradesmen to this new area of Clydeside. ${ }^{166}$ Whereas shipbuilders such as the Stephens of Linthouse directly subsidised dependents' rents from a joint benevolence or relief fund in war, Beardmores appear to have adopted a less formal approach in view of the intensity of unrest and the acute labour shortages. ${ }^{167}$ In any case, so great were the profits being made in manufacturing for the war effort that an indirect subsidy to working families represented a very marginal cost after 1914 .

Like many other shipbuilders also, Beardmores complemented their housing provisions by a range of other services within and without the company itself. In character with his own visions of autocratic command, Beardmore kept a substantial sum in reserve to reward the loyalty and perseverance of his staff, whilst becoming a patron of the more formal

162 Reader, The Weir Group, pp. 29, 86-87, for the American influence and ideas of Weir.

163 Melling, "Clydeside Housing", for some background.

164 Dalmuir and West Scotland Estates Minutes, 22 March 1916.

165 Ibid., 27 June.

166 The Linthouse Magazine, March 1920 , indicates that of $£ 14,450$ collected at the yard in War Relief Fund contributions, almost all came from employees and $£ 5,753$ (or $£ 40 \%$ of expenditure) went upon rent relief.

167 Beardmores, Balance Sheets, 1914-18. 
client association organised by industrialists for supervisors - the Foremen's Mutual Benefit Society. ${ }^{168}$ Housing amenities were reinforced at Parkhead, Airdrie and elsewhere, with female welfare supervision and recreational facilities. ${ }^{169}$ During the closest contacts with the wartime State, Beardmores and other employers emphasised the vital importance of workplace hierarchy as well as adequate labour supply.

\section{The political economy of company housing}

The experience of Scottish shipbuilding indicates that housebuilding remained an important aspect of business activity during the five decades after 1870. As a contribution to the total housing stock at a given period, company housing may not have represented a major initiative in the later nineteenth century, though even here it is clear that employers' efforts have been underestimated both in terms of the direct interventions and their sponsorship of parallel agencies. The uneven development between industries made it almost inevitable that a comprehensive building campaign amongst different firms was highly unlikely, even though the progress seen at a formative stage in the growth of each sector often included a substantial effort by industrial enterprise. Purely speculative activity played a more limited role in the provision of working-class accommodation than has often been assumed, according to recent work. ${ }^{170}$

In order to assess some of the arguments proposed on the motives or rationale for industrial housing, and the supposed transition to private speculative activity after 1870 , we can review the calculations made by shipbuilding employers. These have to be seen at both a general (or macro) level in appraising the development of the industry and the region as a whole, and from the perspective of the individual enterprise. Employers' housing interests may be seen primarily in terms of the labour needs created by industrial production and the deficiencies resulting from market forces in housebuilding, though the specific needs of each sector altered with growth of that industry. Shipbuilders were responding not just to the shortage of workers, but particular grades of employees and skills at different points. Nor do they perceive labour as a neutral factor in respect of quality or loyalty, but were acutely conscious of the need to recruit a steady and disciplined supply of workers.

The significance of scale and resources in explaining the propensity of distinct employers to provide housing must be interpreted with care. It is

168 Ibid.

169 Melling, "Non-Commissioned Officers", for details.

170 Gauldie, Cruel Habitations, p. 21, for example. 
true that only large employers were in a position to spend sufficient capital funding the larger housing schemes after 1870 , but there was no direct correlation between size and expenditure. The largest shipbuilders included Fairfields, without sizeable housing before 1914, whilst the second-rank Stephens and Dennys were amongst the most active of building employers. Where private speculation met the needs of workingclass families to a basic degree, industrialists were reluctant to become deeply involved in the housing market. It would be more accurate to suggest that certain housing projects facilitated underlying trends within the sector towards the concentration of resources and domination of markets by larger firms. The growing integration of steel, ships and arms at John Browns and Beardmores brought into play resources which could easily fund even large construction projects, making a serious contribution at a time of general depression in the building trade. This certainly gave such firms a decided advantage over smaller rivals when large profits were to be made from government orders before and during the war. ${ }^{171}$

Related is the question of the physical location and proximity to centres of population. Shipbuilders requiring large new sites in isolated riverside areas were obviously the larger concerns which were immediately faced with the question of local labour markets. Their impact on local building activity was dramatically demonstrated at burghs such as Clydebank, where almost half of all construction consisted of industrial and commercial contracts in the decade before 1914 (as against perhaps a quarter elsewhere). ${ }^{\mathbf{1 7 2}}$ Even if firms such as Browns and Beardmores did not fully anticipate the extent of housing difficulties when entering such localities, they had strong precedents in the efforts of Thomsons during previous decades for building commitments. The booming conditions after 1909 underlined the disadvantages of labour shortages in this skill-intensive industry, thereby generating a fresh impetus towards housing. Thus it was at the very heights of expansion and growth that the significance of housing was greatest, however scarce resources were and despite higher interest rates due to capital shortages. The following tables for John Browns and Beardmores show housing following a general trend of capital investment as well as being influenced by cyclical expansion.

Shipbuilders certainly appreciated the drawbacks of heavy fixed-capital investment on housing in an industry as subject to violent fluctuations as

171 Payne, "Rationality and Personality", for evidence of growing integration at this period.

172 Rodger, "Speculative Builders", p. 240 , table V, indicates that almost $48 \%$ of fresh Clydebank construction was devoted to industrial and commercial projects in 1903-14, whilst almost $45 \%$ went on housing. 
Table 1. Capital-investment trends and housing at John Brown \& Co., 1904-19

\begin{tabular}{lccccc} 
Year & $\begin{array}{c}\text { General } \\
\text { property* }\end{array}$ & Housing & Ratio $\%$ & $\begin{array}{c}\text { General } \\
\text { capital } \\
\text { investment }\end{array}$ & Housing as \% \\
1904 & 13,696 & 8,885 & 64.8 & 39,980 & 22.2 \\
1905 & 18,407 & 180 & 0.97 & 74,922 & 0.24 \\
1906 & 12,180 & 402 & 3.3 & 79,907 & 0.5 \\
1907 & 10,312 & 62 & 0.6 & 65,276 & 0.09 \\
1908 & 71 & 16 & 22.5 & 10,460 & 0.15 \\
1909 & - & - & - & 9,754 & - \\
1910 & 734 & - & - & 7,458 & - \\
1911 & 59,387 & - & - & 128,178 & - \\
1912 & 33,840 & - & - & 93,952 & - \\
1913 & 5,982 & - & - & 16,678 & - \\
1914 & - & - & - & 112 & - \\
1915 & 500 & - & - & 15,848 & - \\
1916 & 39,636 & 26,443 & 66.7 & 83,650 & 31.6 \\
1917 & 45,174 & 36,331 & 80.4 & 105,006 & 34.59 \\
1918 & 35,516 & 34,974 & 98.4 & 37,507 & 93.2 \\
1919 & 18,617 & 4,985 & 26.7 & 31,824 & 15.6 \\
Total & 294,052 & 112,284 & 38.0 & 800,512 & $14.0^{* *}$ \\
\multicolumn{7}{l}{ This includes housing property. } & & & \\
** Mean. & & & & \\
Tol & & &
\end{tabular}

Source: "Capital Additions", John Browns, Balance Sheets.

theirs, but even greater was the need to create a stable core of skilled workers. The significance of this in terms of new capital additions to plant and machinery, can be gauged also from these figures even though they saw an unusually large amount of investment in both directions before 1914. The condition of war placed extraordinary strains on such employers as well as providing highly favourable market conditions in which to operate, including massive profits for munitions contracts and incentives to engage in housebuilding. In many respects, however, the war represented a sudden acceleration of trends and forces already present in peace, including the integration of different branches of production and the reorganisation of working techniques. ${ }^{173}$ The figures given below were distorted by the attempt of many firms to defer the repair and replacement of machinery until a complete retooling and renovation programme could be claimed against government contracts, but they also indicate a sustained investment in the enlargement of plant and the significance of housing as

173 History of the Ministry of Munitions, IV, Pt IV, p. 95, for example. 
Table 2. Investment at William Beardmore \& Co., 1901-13

$\begin{array}{lcccr}\begin{array}{l}\text { Capital } \\ \text { section }\end{array} & \begin{array}{c}\text { Purchase } \\ \text { price }\end{array} & \begin{array}{c}\text { Capital } \\ \text { expenditure } \\ 1902-10\end{array} & \begin{array}{c}\text { Expenditure } \\ 1911-13\end{array} & \text { Total } \\ \begin{array}{lcccr}\text { Land } \\ \text { Parkhead }\end{array} & 211,245 & 13,895 & 4,006 & 229,146 \\ \text { Mossend } & - & 2,000 & - & 2,000 \\ \text { Dalmuir } & 53,530 & 44,820 & - & 98,350 \\ \begin{array}{l}\text { Building } \\ \text { Parkhead }\end{array} & 62,942 & 183,533 & 35,605 & 282,080 \\ \text { Mossend } & - & 24,556 & 3,027 & 27,583 \\ \text { Dalmuir } & - & 205,457 & 6,470 & 211,927 \\ \begin{array}{l}\text { Housing } \\ \text { Parkhead }\end{array} & - & & & \\ \text { Mossend } & - & 5,601 & 500 & 6,101 \\ \text { Dalmuir } & - & 27,103 & 2,697 & 8,697 \\ \begin{array}{l}\text { Fixed plant } \\ \text { \& machinery }\end{array} & & & & 28,693 \\ \text { Parkhead } & 481,767 & 703,073 & 179,074 & 1,363,914 \\ \text { Mossend } & - & 172,581 & 6,951 & 179,532 \\ \text { Dalmuir } & - & 486,609 & 55,475 & 542,084 \\ \text { Ex Govan } & 26,085 & 14,702 & - & 40,787 \\ \text { \& Lanf. } & & & & \\ \begin{array}{l}\text { Docks } \\ \text { Dalmuir }\end{array} & & & & \\ \text { * Previously Govan Lancefield Account. } & & & & \\ & & & & \end{array}$

industrial infrastructure. ${ }^{174}$ In terms of total additions, housing represented as much as $14 \%$ of total capital investment at John Browns in the years 1915-19, and more than $4.5 \%$ at Beardmores in the same years.

Looking more closely at the patterns of investment seen at such enterprises before 1920, there is a marked trend in most of the concerns towards the reorganisation of communications within the yards and shops coupled with a degree of mechanisation before the war. ${ }^{175}$ There was also an unmistakable movement towards the systematic regulation of work and the workforce after 1870, accelerating from the 1890's. Even the solid family enterprises of Dennys, Stephens and Elders were amongst the most progressive of innovators in this respect, as scale increased and the technical

174 Stephen Minutes, 3 November 1916. The Board noted that given the "probability of having to make heavy payments under the Excess Profits Acts the directors consider it most advisable to consume the resources of the Company as much as possible." 175 See Tables 1-4. 
Table 3. General trends in investment at John Browns, 1904-19

$\begin{array}{rccccccr}\text { Year } & \begin{array}{c}\text { Ship- } \\ \text { building } \\ \text { machinery }\end{array} & \begin{array}{c}\text { Engine- } \\ \text { work } \\ \text { machinery }\end{array} & \begin{array}{c}\text { Boiler- } \\ \text { works } \\ \text { machinery }\end{array} & \begin{array}{c}\text { General } \\ \text { equipment }\end{array} & \text { Dock } & \text { Rail } & \text { Total } \\ 1904 & 6,698 & 10,604 & 5,499 & 623 & 60 & 2,800 & 26,284 \\ 1905 & 9,355 & 16,687 & 2,557 & 27,677 & 148 & 91 & 56,515 \\ 1906 & 3,969 & 8,491 & 845 & 41,614 & 12,799 & 6 & 67,724 \\ 1907 & 958 & 3,273 & 6,639 & 32,036 & 17,059 & - & 54,964 \\ 1908 & 118 & 5,245 & - & 1,260 & 3,765 & - & 10,388 \\ 1909 & 2,535 & 849 & - & - & 6,316 & - & 9,700 \\ 1910 & 449 & 4,777 & - & 1,316 & - & - & 6,542 \\ 1911 & 43,029 & 15,211 & 398 & 3,955 & 544 & 5,654 & 68,791 \\ 1912 & 17,736 & 418 & 9,522 & - & 26,763 & 5,672 & 60,111 \\ 1913 & 8,828 & 1,819 & - & - & - & 48 & 10,695 \\ 1914 & - & 112 & - & - & - & - & 112 \\ 1915 & - & 2,486 & - & - & - & - & 2,486 \\ 1916 & 22,480 & 17,659 & 2,047 & 1,827 & - & - & 44,013 \\ 1917 & 37,448 & 17,001 & 450 & 4,934 & - & - & 59,833 \\ 1918 & 1 & 10 & 11 & 1,835 & - & 179 & 2,036 \\ 1919 & 12,056 & - & - & - & - & 1,151 & 13,207\end{array}$

Source: "Capital Additions", John Browns, Balance Sheets.

complexities of production grew. It is inaccurate to equate family control with either limited resources or traditionalist management, though shipbuilding dynasties did retain a large amount of direct control over the planning and organisation of output. What seems more likely is that the growth in scale and the coming of limited liability imposed a more rigorous financial and organisational structure upon the enterprise, including the elaboration of management hierarchies. These tendencies can only be understood within the specific context in which they developed, and with the continuing response of a powerful workforce directly in view. The resistance of organised labour to the imposition of fresh conditions on management terms is evident in the persistent struggles over machinery, apprenticeship, demarcation, payment system and workplace discipline. In this context the role of the supervisor (foreman and underforeman) became a major issue in shipbuilding as well as engineering. ${ }^{176}$ Welfare schemes organised by employers' associations became part of a strategy deployed to weaken the hold of trade societies over such key grades.

It would be equally difficult, however, to portray company housing simply as a narrow strategy rather than the neutral initiative of employers

176 A. Williams, Life in a Railway Factory (Newton Abbot, 1969), pp. 56-57, 78-80 and passim, for a contemporary description of the changing role of the works foreman. 
Table 4. Investment at Stephens \& Sons, 1901-19

Year

Ground and buildings

Valuation Additions Depreciation

$\begin{array}{ll}1901 & 111,454 \\ 1902 & 111,971 \\ 1903 & 112,049 \\ 1904 & 123,014 \\ 1905 & 123,014 \\ 1906 & 123,689 \\ 1907 & 127,766 \\ 1908 & 130,139 \\ 1909 & 134,731 \\ 1910 & 135,601 \\ 1911 & 137,043 \\ 1912 & 138,881 \\ 1913 & 145,030 \\ 1914 & 174,483 \\ 1915 & 178,163 \\ 1916 & 212,473 \\ 1917 & 213,360 \\ 1918 & 216,889 \\ 1919 & 264,158\end{array}$

$$
\begin{array}{r}
- \\
517^{*} \\
78^{*} \\
10,965^{*} \\
- \\
675^{*} \\
4,077^{*} \\
2,373 \\
4,592 \\
869 \\
1,442 \\
1,839 \\
6,449 \\
31,154 \\
5,680 \\
36,465 \\
2,824 \\
5,955 \\
50,046
\end{array}
$$

Machinery

Valuation Additions Depreciation

* This figure has been calculated for the present table. These are gross additions minus an estimated depreciation of $1.17 \%$ per annum.

** These are net additions. Gross addition would be affected by an estimated $6 \%$ depreciation (based on experience of $1909-14$ ), or $5.93 \%$ on machinery.

Source: Alexander Stephen \& Sons, Annual Balance Sheets, 1901-19.

needing adequate labour. Housing was simply too costly and the workers too well organised to use accommodation as a manipulative or coercive instrument against a workforce. There is little sign that such aggressive managerialists as W. D. Weir, J. R. Richmond and Stephen Alley expressed an interest in housing before 1914, though the experience of war had a profound effect on their outlook also. Where their contemporaries felt compelled to provide housing, however, strategic considerations and management objectives are certainly evident. Accommodation was carefully graded to reinforce the hierarchical structure of authority at work, not only on Clydeside but in other shipbuilding regions. ${ }^{177}$ Certain industrialists were willing to provide subsidised dwellings for their key supervisory and managerial stratum at Clydebank, just as Dennys had offered 177 "Industrial Housing", in: Industrial Welfare, V (1923), pp. 186-87, for the Furness Shipbuilding Company at Teeside, and their distinction in housing the three groups of staff, supervisory and manual employees. 
Table 5. Profits at William Beardmores, 1914-18

\begin{tabular}{|c|c|c|c|c|c|c|}
\hline Section & 1914 & 1915 & 1916 & 1917 & 1918 & Mean \\
\hline Parkhead & 545450 & 590073 & 849759 & 920464 & 1018316 & 784812 \\
\hline Mossend & -2307 & -18366 & 172811 & 304782 & 202647 & 131913 \\
\hline Coatbridge & - & 3069 & 4381 & -15710 & 1890 & -1592 \\
\hline Dalmuir & 22768 & 101623 & 118840 & 371790 & 470685 & 208034 \\
\hline Aero Engine & 1540 & 11008 & 16068 & 11730 & 6900 & 9449 \\
\hline National PF 1 & - & - & - & 59070 & - & 59070 \\
\hline Rents & 1166 & 940 & $268^{3}$ & 1311 & 1451 & 1027 \\
\hline $\begin{array}{l}\text { Fee and com- } \\
\text { mission }\end{array}$ & 106 & 238 & 6366 & 3396 & 146 & 2050 \\
\hline Gross profit & 523187 & 688584 & 1233582 & 1656835 & 1702035 & 1160845 \\
\hline and interest & 157685 & 111274 & 146163 & 332645 & 312074 & 211968 \\
\hline Depreciation & 106350 & $245110^{4}$ & 219329 & 186364 & 161734 & 183777 \\
\hline Reserves & 40000 & 100000 & 260000 & 50000 & 330000 & 156000 \\
\hline Net Profit ${ }^{2}$ & 219142 & 232200 & 592994 & 1087826 & 898229 & 606078 \\
\hline
\end{tabular}

Source: tabulated from University of Glasgow Deposit 100 8/14-18.

favourable conditions for purchase to foremen of an earlier generation. These motives became even stronger during the struggles of war, as tremendous pressures were placed on management authority and foremen became the emissaries of an embattled State. Previously unconvinced of the needs of their underforemen, the Brown directors finally agreed to a separate housing project at Whitecrook during 1915-16. ${ }^{178}$

The decision to subsidise supervisory habitations at the turn of the century was in sharp contrast to the calculations carefully prepared on the renting of workmen's dwellings. There is little doubt that the general standard of company housing was reasonably good, being free from the jerrybuilding practices which accompanied the speculative booms in many areas. John Browns told the Ministry of Munitions in 1916 that they were able to offer a tenement flat of two rooms plus kitchen as a "special inducement to men to adopt pneumatic rivetting", given the cramped conditions in which the bulk of working-class families lived. ${ }^{179}$ The stone 178 Bell, "Memorandum on the Shortage of Ironworkers", for the planning of Whitecrook phase with 83 apartments; Oral-history transcripts on Industrial Supervision, No 2, p. 8.

179 John Browns to Ministry of Munitions, 5 October 1916, specified two rooms plus kitchen. 
Table 6. Housing investment at William Beardmores, 1915-19

$\begin{array}{lrcc}\text { Year } & \begin{array}{c}\text { Total capital } \\ \text { investment }\end{array} & \begin{array}{c}\text { Housing } \\ \text { investment }\end{array} & \text { Housing as \% } \\ 1915 & 1,428,764 & 18,950 & \\ 1916 & 899,917 & 41,110 & 1.3 \\ 1917 & 592,693 & 32,881 & 4.5 \\ 1918 & 508,592 & 36,588 & 5.5 \\ 1919 & 275,386 & 38,925 & 14.1 \\ \text { Total } & 3,705,352 & 168,454 & 4.55^{*}\end{array}$

* Mean.

Source: id.

cottages provided for foremen in the employ of Stephens, Dennys, Yarrows, Browns and Beardmores were again considerably above what most working men might aspire to before 1914.

In planning their projects, employers reviewed the careful estimates of rental yield, Browns anticipating a return of $4-5 \%$ net, after the repayment of interest on mortgage loans raised for building. The company actually shared the immediate costs of construction with contractors, who contributed perhaps one third of the outlay before completion. ${ }^{180}$ Browns fully expected to recoup a reasonable return on their own investment, even after the loan interest was accounted for. This raises questions about previous assumptions of investment returns, and indicates a building deficiency even when good rents could be secured. ${ }^{181}$ Whereas speculative builders were often unable to raise sufficient capital to invest in housing with the guarantee of ready demand, industrialists underwriting loans and building overheads were confident of securing steady rents. Beardmore was likewise determined to net a similar return on Dalmuir construction before approving a further phase of building in 1914, particularly when wartime inflation threatened the basis of calculations. Yet the figures of rents realised at Dalmuir and elsewhere show that return on housing investment as currently valued was $5.5 \%$ in 1903 , falling to $1.4 \%$ by 1910 . This suggests that cyclical fluctuation and resistance to rents forced some flexibility in rent policy before the war, though Beardmores seem to have joined in general rent increases in 1913-14, thereby raising returns to almost $4 \%$ on valuation. In response to the rent strikes and housing unrest, as well as the

180 John Browns, Housing Plans, UCS 1 23/2; Bell, "Memorandum on Shortage of Ironworkers".

181 Gauldie, Cruel Habitations, p. 189, for comments on the four per cent philanthropy of Salt and subsequent level of returns. 
Table 7. Properties and rental yield at William Beardmores, 1903-13

$\begin{array}{lcccc}\text { Year } & \text { Property } & \text { Valuation } & \text { Rental } & \text { \% Yield on value } \\ 1903 & \text { Auburn Place } & 4,601 & 252 & 5.5 \\ 1904 & ? & ? & ? & ? \\ 1905 & \text { Auburn, Dalmuir, Duke } & 11,040 & 400 & 3.6 \\ 1906 & \text { Auburn, Dalmuir, Duke } & 15,319 & 508 & 3.3 \\ 1907 & \text { Auburn, Dalmuir } & 29,646 & 1,041 & 3.5 \\ 1908 & \text { Dalmuir } & 31,809 & 1,021 & 3.2 \\ 1909 & \text { Dalmuir } & 31,724 & 785 & 2.5 \\ 1910 & \text { Dalmuir } & 31,776^{*} & 452 & 1.4 \\ 1911 & \text { Dalmuir } & 31,973^{*} & 610 & 1.9 \\ 1912 & \text { Dalmuir } & 31,024^{*} & 743 & 2.4 \\ 1913 & \text { Dalmuir } & 31,921^{*} & 645 & 2.0\end{array}$

* These figures include depreciation.

Source: calculated from figures in William Beardmores, Balance Sheets and Accounts, University of Glasgow Deposit $1008 / 1$.

Table 8. Housing rents at William Beardmores, 1914-18

$\begin{array}{lcccc}\text { Year } & \text { New Investment } & \text { Valuation* } & \text { Rental Yield } & \text { \% Return } \\ 1914 & - & 30,907 & 1,166 & 3.8 \\ 1915 & 18,950 & 48,869 & 940 & 1.9 \\ 1916 & 41,110 & 89,015 & 268 & 0.3 \\ 1917 & 32,881 & 120,957 & 1,311 & 1.0 \\ 1918 & 34,913 & 156,630 & 1,451 & 0.9 \\ \text { Total } & 127,854 & 446,378 & 5,136 & 1.6\end{array}$

* Valuation is calculated as previous figure plus new investment and minus $2.5 \%$ depreciation. Depreciation only applies to the pre-war housing which is depreciated during the war years.

Source: id.

shortage of workers, the company apparently relaxed rents whilst continuing construction in 1915-16, driving yields to $1 \%$ or less for the remainder of the war. The figures in Tables 7 and 8 again suggest the primary concern with labour supply and manufacturing profits, as much as the impact of enlistment and tenant protest on housing policies. It is also significant that during the earlier housing for senior supervisors at John Browns, the company had approved the construction on the basis of an annual loss of $£ 190$ per annum in interest repayments. ${ }^{182}$ Certain grades of worker were given a privileged position in welfare benefits, later to evolve into a widespread practice of selective rewards.

182 Progress Reports, No 10, for estimates. 
Measuring the consequences of these housing schemes for the efficiency and general profitability of the individual concern is problematical. In many situations they appear to have given the employer a competitive edge which more than compensated the low returns achieved on such housing investments, more particularly during the extraordinary conditions of wartime production. On its own, housing was certainly no substitute for effective management and marketing as the record of the Dalmuir shipyard before 1914 painfully demonstrated. Nor were the strategic gains obvious at a time when industrial and social unrest swept through Clydeside in 1915-16, affecting company housing as well as private landlords. Yet the fact remains that most of those shipbuilders imaginative enough to realise the advantages of housing were also those who continued to realise large profits before 1920 (and none more so than Beardmore after 1914). What we are dealing with is not necessarily an abstract equation of marginal utility, but the subjective perceptions of industrialists preoccupied with the problems of profitability and workplace relations. In their eyes at least, prepared estimates of returns had to be combined with a realistic appraisal of shifting conditions and varying opportunities.

\section{Employers and the politics of housing provision}

The comparison of employers' activities in housing provision after 1870 reveals not only important qualitative differences in the types of accommodation provided, but also a gradual change in the direction of responsibilities. Direct intervention in the housing market remained an important reserve for industry, but there was a growing trend towards the sponsorship of autonomous initiatives and negotiation with State agencies in the finance of construction. The promotion of working-class self-help in organising housing investment was already an established feature of provision in the later nineteenth century, when Dennys supported the friendly-society movement at Dumbarton. Indeed, it is likely that encouragement of building associations was already more common than company building and that Ackroydon is a far more representative example of business initiatives than Saltaire by the 1870's. ${ }^{183}$ As the scale and definitions of the "housing problem" expanded after 1900, the resources of friendly or utility societies were overwhelmed and there arose the powerful campaign in favour of legislative intervention. Despite the limited contribution of the measures enacted after 1890, we can trace a shift towards State support for schemes sponsored by employers before 1914 .

${ }^{183}$ W. Ashworth, "British Industrial Villages in the Nineteenth Century", in: Economic History Review, Second Series, III, pp. 379-80 and passim. 
Shipbuilders were certainly not unique in this respect, nor in the dramatic impact which the war was to have upon their outlook and commitment to housing. What gave industrialists in regions like West Scotland their significance was the crucial strategic role they performed in the wartime economy and its military production. Labour shortages and strikes in coalmines or railways hampered the war effort, but stoppages in munitions and shipbuilding districts threatened the State itself. It was for these reasons that Rowntree and Hyde were placed in charge of welfare at the Munitions Ministry, responsible to Addison and Lloyd George, whilst business leaders from Weir to Mond were brought into government. Despite the initial resistance from heavy industry to the schemes of Rowntree's department, progressive managerialists such as Stephen Alley later became strong supporters of Hyde's Industrial Welfare Society formed after the war. ${ }^{184}$

When Alley sold his shipbuilding interests to Beardmore in 1918 and transferred his waggon-building operations to Shrewsbury, in South England, his Sentinel Company used a fifty-acre site for a large model-housing scheme to accommodate the skilled engineering workers he transported there. ${ }^{185}$ The firm facilitated the formation of a Public Utility Society, eligible for government assistance and with a degree of participation by the employee-tenants in the administration of the scheme. The interdependence of industrial capital and housing property was graphically demonstrated in the design of electrical-power supplies from the factory for the heating of the surrounding dwellings. ${ }^{186}$ Such projects were also pioneering advocates of the new building materials which restricted the use of craft labour, so vociferously championed by W. D. Weir. ${ }^{187}$

Thus employers contributed in a very direct way to the growing influence of the garden-city movement, which had a pervasive influence on architects and politicians alike after $1910 .{ }^{188}$ Contemporary writers for industrial magazines emphasised the direct relationship between housing problems and unrest at work and in society, arguing for model-factory estates which would found communities of "good and contented work-

184 E. Sidney, The Industrial Society, 1918-68 (London, 1968), p. 5.

185 J. Hughes and M. Thomas, "The Sentinel": A History of the Sentinel Waggon Works (London, 1969), p. 120.

186 "Industrial Housing", in: Journal of Industrial Welfare, II (1920), pp. 156-58, for Sentinel progress at Shrewsbury.

187 "The Housing of Industrial Workers", in: Industrial Welfare, V, pp. 91-93.

188 "Housing as a Welfare Enterprise: Industry does what states have failed to do", in: Journal of Industrial Welfare, II, p. 55; R. L. Reiss, "Welwyn Garden City", in: Town Planning Review, VIII (1919-20), pp. 179ff. 
ers". ${ }^{189}$ In a period when Whitley proposals gained some popularity amongst employers, such writers also advised real participation by the workforce in administering their housing societies if not shaping their engineered environment. ${ }^{190}$ The ideology of town planning and welfare provision can be exaggerated, but it is essential to identify it as an ideology when appraising the contributions claimed by such industrialists as Lever, Cadbury or Rowntree himself.

The growing convergence of industrial and State interests in housing after 1900 also had important implications for the progress of social policy in Britain. There continued to be important additions to the existing stock in sectors as diverse as coal mining, textiles, railways and steel, with employers in the chemical and arms industries also extending housing commitments before and during the war. These were not sufficient to deflect the growing campaign against poor and inadequate dwellings after 1900 , even when supported by government subsidies. It is notable that housing protests and industrial conflicts occurred after 1914 in some of the model settlements constructed to meet local needs, including rent strikes at the new town of Rosyth. ${ }^{191}$ Much more prolonged were the bitter complaints at company housing in the coal-mining districts, which culminated in the protests before the Sankey Commission after the war. Employers were unable to cope with the sheer range of industrial and social issues that crystallised around the housing question at this point.

The initiatives which the post-war government did attempt under Addison and Mond owed a considerable amount to the experiments and schemes supported by the Munitions Ministry and War Office. Recent research has uncovered important links between the efforts of wartime ministries and personnel, and the housing strategies adopted in the turbulent years of peace. ${ }^{192}$ Even if the resources of industry were depleted by the recession after 1920 , so also was the impetus towards serious social reconstruction which began in the later years of war. Industrial housing thereafter became a matter of State subsidies and selective initiatives, with expanding enterprises encouraged to found whole new settlements to es-

189 A. Trystan Edwards, "Factory Estates - A Plan to Banish Industrial Unrest", in: Works Management, III (1920), p. 235.

190 Ibid., pp. 235-36; A. Hall, "Housing for Industrial Welfare", in: Journal of Industrial Welfare, II, p. 255, for a more authoritarian and less co-operative emphasis.

191 Dundee Courier 30 July 1919, for Rosyth Rent Strikers of 1919; it is noticeable that the "model" estate of Penistone built by Cammell Lairds also experienced serious unrest at this period, largely as a result of workplace disputes over industrial supervision.

192 Swenarton, Homes Fit for Heroes, pp. 110-11, for the subsequent influence of Ministry of Munitions personnel on housing development, including the estate planning ideology. 
cape the depressed backwaters of established industry. Shipbuilders were amongst those unable to take this option and slid into decline for much of the inter-war period, carrying the boom towns of previous prosperity into decay with them.

\section{Conclusion}

This article has not attempted to argue that company housing constituted a major proportion of total housing stock after 1870 , but rather that the complete range of housing activities by employers must be considered a significant aspect of both management policies and construction initiatives at this period. Our understanding of such activities must begin with an analysis of particular industries in the development of regional and national economies, for the employer's fundamental concern is with the supply of labour and the regulation of local labour markets. The deployment of this labour in an efficient and disciplined way remains the guiding principle of his management policies, which involves the effective division of labour in ways compatible with hierarchical authority. Only by ignoring the underlying relationships and antagonisms implicit in this arrangement can we perceive "market conditions" as neutral factors. The alternative analysis suggested here emphasises the persistence of conflict during the birth and evolution of industrial capitalism, and its presence in the structuring and organisation of labour markets themselves.

Whilst employers share certain general needs in regard to labour, they compete in the attraction and utilisation of workers from an early stage in capitalist development. Industrial housing can be examined at two stages: in the interrelationship of distinct areas of production and market conditions, and in the competitive activities of individual concerns whose primary interest remains that of manufacturing production. It is inaccurate to imply that there is a clear shift from company to speculative activity after 1870 , precisely because the market forces and levels of accumulation experienced in each sector (including building) were so erratic and uneven. The vicissitudes of Scottish housebuilding compelled industrialists to intervene in the housing market at a crucial period of growth and profitability in shipbuilding. To explain the character and motivation of the employers, or the significance of housing for the development of the enterprise, we need to explore the management strategies of each company. The high degree of specificity in organisation and innovation extended even to separate firms, just as certain concerns faced peculiar industrial-relations difficulties because of their record and reputation in man-management. 
These responses can certainly be connected to broader trends in the changing structure of the industry and the pattern of industrial conflicts occurring at this period. In Scottish shipbuilding, housing assisted the movement towards integration of steel, ships, engineering and arms for some giant concerns before and during the war. It was also shaped by the extension of management hierarchies and the renewed emphasis on closer supervision seen in those yards advocating systematic management. The role of housing in the wider spectrum of labour policies became apparent during the war years, profoundly influencing the attitude of many masters to the government-sponsored welfare movement. Contacts with State authorities formed only one area where employers supported autonomous agencies of housing provision, the friendly societies of an earlier generation still playing a vital part in the reconstruction era of 1918-23 as "utility societies". The social and cultural implications of self-help amongst the respectable working class, apparent to the Dennys in the 1870's and 1880's, survived in an attenuated form during the garden-city movement and the creation of model communities after 1918. Industrial mobilisation and class conflict had weakened many of the values associated with "artisan" lifestyles, but the efforts by employers and policy-makers to create the contented community remained as persistent as ever.

It is in this light that we should locate the schemes inaugurated by the Levers, Rowntrees, Cadburys and others. They were certainly less unique than is often suggested, with New Earswick and Bourneville depending on the public utility society and government relief as much as Alley's new factory estate near Shrewsbury. Their architects doubtless had a deep concern for the living conditions of their workforce, but Clyde shipbuilders too were anxious to create a setting for civilised capitalism and their efforts (if less celebrated) were almost certainly more typical. It was the heavy industries such as coal, railways, steel and shipbuilding which remained the great holders of industrial housing in the inter-war period, despite the great waves of tenant protests mounted against profiteering and landlordism before 1920. If the Levers were more successful at advertising their model garden suburbs, it was the Yarrows, Beardmores and John Browns who had weathered the bitter years of conflict with profits intact. 